\title{
Elevers möjligheter till lärande av matematiska resonemang
}

\author{
Jonas Jäder
}

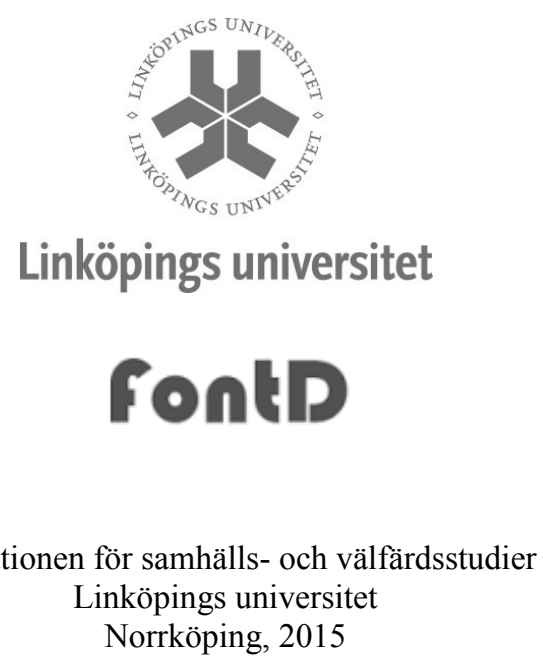

Institutionen för samhälls- och välfärdsstudier

Norrköping, 2015 


\section{Elevers möjligheter till lärande av matematiska resonemang}

Licentiatavhandling

Försvarades 4 mars 2015 klockan 13.30

Opponent: Professor Mogens Niss, Roskilde universitet

Copyright (C) Jonas Jäder

Linköpings universitet

Institutionen för samhälls- och välfärdsstudier

60174 Norrköping, Sverige

ISSN 1652-5051

ISBN 978-91-7519-099-0

Denna licentiatavhandling ingår även i serien: Studies in Science and Technology Education, No 87

Nationella forskarskolan i Naturvetenskapernas, Matematikens och Teknikens didaktik, FontD,

http://www.isv.liu.se/fontd, tillhör Institutionen för samhälls- och välfärdsstudier (ISV) och Styrelsen för utbildningsvetenskap (SUV) vid Linköpings universitet. FontD är ett nätverk av följande medverkande lärosäten: Luleå tekniska universitet, Mälardalens högskola, Mittuniversitetet, Linnéuniversitetet och universiteten i Umeå, Karlstad, Linköping (värd), Göteborg och Lund samt högskolorna i Malmö, Kristianstad, Halmstad och Gävle. FontD publicerar skriftserien Studies in Science and Technology Education, ISSN 1652-5051.

Tryckt av LiU-Tryck, Linköping 2015 
"I'm not the same as I was long ago, I've learned some new things and I hope that it shows" (N. Young)

"When it comes to luck you make your own" (B. Springsteen)

"Gå ut o var glad, din jävel!

Gå ut och var vacker och stolt hela vintern

Gå fort och le genom shoppingcentrat

Du kan om du vill"

(U. Lundell) 


\section{Förord}

När jag sitter och skriver det här känns det som jag nått upploppet. Än är jag inte i mål, men mycket möda, slit, och framför allt glädje, under tre års tid har tagit mig till en plats där ett par sista stavtag kan föra mig över mållinjen. Likt ett vasalopp krävs givetvis en mängd träning och rejält stöd för att nå målet. Och likt ett vasalopp kan även den här tiden då min licentiatavhandling, och de tre studierna jobbats fram, ses som en träning. En träning för nya, framtida lopp.

Jag skulle vilja passa på att tacka Hudiksvalls kommun som gett mig chansen att genomföra dessa forskarstudier. Som lärare likväl som nu i detta forskningsarbete har en av mina drivkrafter hela tiden varit att utveckla skolan och mer specifikt matematikundervisningen, för att möjliggöra ett större lärande för eleverna. I den processen är all personal på skolan oerhört väsentlig, och läraren den enskilt viktigaste faktorn. Det är också med mina kollegor i tanken jag skrivit den här kappan. För trots att de tre artiklarna är skrivna $i$ ett forskningssammanhang med allt vad det innebär, så bottnar teorier, syften, resultat och diskussioner i den verklighet som möter oss lärare i klassrummet varje dag. Ett speciellt tack vill jag rikta till de av er som släppt in mig i era klassrum med filmkamera och anteckningsblock, och till de elever som välvilligt ställt upp och löst uppgifter och samtalat med mig.

Jag har haft glädjen av fantastisk handledning, som alltid varit målfokuserad och med mitt välbefinnande i centrum. Oräkneliga är de Skypemöten vi haft där det hela tiden visats en tro på projektet och där vägen mot målet analyserats på ett konstruktivt sätt. Jag hyser den allra största respekt för min huvudhandledare, Michael Hörnquist såväl som människa som i hans yrkesroll. Ett stort tack vill jag rikta till dig Michael. Ett tack vill jag också rikta till min biträdande handledare Konrad Schönborn, tillika koordinator för forskarskolan, Font D. Konrad har i allra högsta grad bidragit till den positiva miljö som jag fått befinna mig i under tre års tid, och har med sin framåtanda och klokhet fått mig att hela tiden se nya detaljer.

Flera är också de som under dessa tre år läst och kommenterat mina texter, från de allra första utkasten på forskningsplaner till den kappa och de tre artiklar som utgör denna avhandling. De insikter och nya perspektiv som jag fătt av alla kloka människor har jag verkligen uppskattat. Ett stort tack till er alla. Font D med dess ordförande Lena Tibell i spetsen är också värda ett tack för den plattform som erbjudits mig och den inramning av hela långa loppet som har skapats. Jag har fått åka tillsammans med en fantastisk skara människor omkring mig. I klungan av människor utkristalliserade sig tidigt en person i ett spår intill, som hela tiden drev på framåt med aldrig sinande energi. Så fort jag fått bakhalt har han stannat och hjälpt mig valla om, och dessutom bjudit på, såväl något att äta som ett leende. Jag har helt enkelt mycket att tacka Johan Sidenvall för. 
Längs vägen har jag dessutom haft glädjen att få arbeta tillsammans med två mycket kompetenta forskare, Johan Lithner och Lovisa Sumpter. Johan och Lovisa har varit högst delaktiga i de projekt jag haft längs vägen och bidragit med så mycket visdom. Båda två har helhjärtat hjälpt mig driva på framåt, och med sin erfarenhet, tillsammans med mig nått flera etappmål. Jag är tacksam för att ha fått lära känna er båda, och för den insyn i forskningsvärlden ni bidragit med.

Vad behövs då, förutom ordentliga förberedelser, för att klara av ett Vasalopp på bästa möjliga sätt? Jo, givetvis blåbärssoppa! Och den har jag fått mig serverad av vänner och familj längs hela vägen. Ingen nämnd och ingen glömd. Men utan all den support jag fått från mina tre underbara barn, Rasmus, Love och Alvin hade loppet känts så oändligt mycket längre. De har sett till att soppan hela tiden varit varm och alltid kommit med hejarop. När jag gått i mål kan vi ägna mer tid till att valla skidor tillsammans och göra gemensamma utflykter i skogen. Den här är till er. Inte nu, men om några år är det kanske fett coolt eller möjligen swag $:$

/Jonas Jäder, Hudiksvall i snöskrud, februari 2015 


\section{Sammanfattning}

En av anledningarna till varför elever har svårigheter med matematik i skolan är att utantillinlärning utgör grunden för utbildningen för många av eleverna. Procedurella och konceptuella kunskaper behövs för att skapa en bred matematisk kompetens. Eleverna lär sig bara det som de får en möjlighet att lära sig, vilket innebär att de möjligheter till lärande som erbjuds eleverna i skolan måste beaktas. Ett väletablerat ramverk som gör det möjligt att analysera de resonemang som krävs för att lösa läroboksuppgifter samt de resonemang som används av eleverna vid uppgiftslösning har använts för att undersöka möjligheterna att lära sig resonera matematiskt. Genom att använda ramverket möjliggörs en mer förfinad diskussion av vilken typ av kunskap som används av eleverna. Ramverket skiljer på kreativa matematiska resonemang, där en lösning måste skapas av eleven, och imitativa resonemang som bygger på utantillinlärning eller imitering av en tillgänglig lösningsalgoritm. Möjligheterna att lära sig beror på klassrummets normer som har förhandlats fram mellan elever och lärare. Dessa normer påverkas i sin tur av flera faktorer. I denna avhandling diskuteras läroboken, både som en, av flera bilder, av undervisningen och utifrån hur den används i klassrummet, samt elevernas uppfattningar om matematik. I avhandlingen ingår tre studier. Den första studien består av en analys av uppgifterna, med avseende på kraven på resonemang, i läromedel från tolv länder, i fem världsdelar. I den andra studien har elevers resonemang då de arbetar med uppgifter från läroboken i klassrummet analyserats. I den tredje studien används en tematisk analys för att undersöka de uppfattningar som eleverna visar upp, vilka sedan kopplas till de resonemang som används.

Resultaten visar att läroböckerna från tolv olika länder har en liknande andelen uppgifter som kräver att eleverna använder kreativa matematiska resonemang. I genomsnitt krävde ungefär var tionde uppgift ett mer genomgripande kreativt matematiskt resonemang. Resultaten visar även att elever i den svenska gymnasieskolan främst löser de första, lättare uppgifterna, där andelen uppgifter som kräver ett kreativt matematiskt resonemang är lägre. Eleverna använder också i stor utsträckning imitativa resonemang. Möjligheterna för elever att träna sig på kreativa matematiska resonemang verkar utifrån mina resultat vara begränsade. Då elever guidar varandra genom uppgiftslösning verkar det som att fokus främst ligger på att komma fram till ett svar som överensstämmer med facit. Inte heller då elever får hjälp av en lärare verkar möjligheter till annat än imitativa resonemang skapas. Eleverna indikerar dessutom uppfattningar om att matematiska uppgifter i de allra flesta fall ska kunna lösas genom ett imitativt resonemang och att utantillinlärning därför bör vara en central del av undervisningen. Lärarens roll i klassrummet är viktig för att skapa och utveckla de gemensamma klassrumsnormerna. Stor vikt bör läggas vid vilka uppgifter och vilka läromedel som används i undervisningen. Även elevernas sätt att arbeta i klassrummet måste beaktas i relation till möjligheterna till lärande, och den matematiska förståelsen bör spela en större roll. 


\begin{abstract}
One of the main problems with learning difficulties in mathematics is that rote-learning becomes the very foundation of mathematics for many students. Procedural as well as conceptual knowledge is needed to build a broad mathematical competence. Students learn only what they get an opportunity to learn, which means that we must consider what opportunities to learn are given to school students. For the purpose of exploring what opportunities are available to learn to reason mathematically, a well established framework is used to analyze the reasoning required by textbook tasks as well as the reasoning used by students. The framework was used to refine the discussion of what type of knowledge is used by the students. Application of the framework distinguishes between creative mathematical reasoning, where a solution has to be created by the student, and imitative reasoning which is based on rote learning or following an existing template. Opportunities to learn depend on the classroom norms that have been negotiated between students and teacher. These norms are influenced by several factors. This thesis deals with the textbook, both as one of several pictures of the education, and in terms of how it is used in the classroom, as well as students' beliefs about mathematics. There are three studies included in the thesis. In the first study, tasks in mathematics textbooks used in secondary school around the world are analyzed concerning the reasoning requirements. For the second study an analysis of students reasoning during textbook task solving in the classroom has been conducted. In the third study a thematic analysis has been used to explore students' beliefs about mathematics and relate these beliefs to the reasoning used.
\end{abstract}

Results from analyzing textbooks from twelve different countries paint a similar picture when it comes to the proportion of tasks requiring students to use creative mathematical reasoning. On average, only every tenth task required creative mathematical reasoning to a greater extent. Furthermore, students in the Swedish upper secondary school level mainly focus on solving the easier, earlier tasks and also mainly use imitative reasoning. Opportunities for students to use creative mathematical reasoning seem limited. When students guide each other during task solving, the main focus seems to be to reach a conclusion in terms of an answer corresponding to that given in the answer-section of the book. Moreover, guidance from a teacher does not seem to lead to anything other than imitation of a procedure. Students also indicate their beliefs by expressing that most tasks should be possible to solve using imitative reasoning, and that therefore, rote learning is a central part of mathematics education. This places pressure on teachers to carefully reflect on what tasks and textbooks they use in their teaching, and also what types of classroom norms they wish to present. The manner in which students work in the classroom also needs consideration, where a greater focus should be directed toward understanding. 


\section{Avhandlingens studier}

Avhandlingen baseras på följande tre studier:

1. Reasoning requirements in school mathematics textbooks: an analysis of books from 12 countries (Inskickad för publicering, mars 2015) - Jonas Jäder, Johan Lithner \& Johan Sidenvall

Avseende den första studien har undertecknad ansvarat för detaljutformningen av analysverktyget utifrån ramverket (Lithner, 2008), analysprocessen avseende såväl kategorisering av läroboksuppgifter som analys av dessa data, urvalet av läromedel samt textbearbetning.

2. Students' reasoning in mathematical textbook task-solving (Accepterad för publicering $i$ International Journal of Mathematical Education in Science and Technology, DOI 10.1080/0020739X.2014.992986. Tillgänglig online) Johan Sidenvall, Johan Lithner \& Jonas Jäder

I studie 2 består undertecknads bidrag av ett kontinuerligt samarbete med de övriga författarna kring studiens upplägg och genomförande. Detta arbeta har stärkt det använda ramverket och innefattar delaktighet i processen att utforma analysverktyget, tolkningar av empirin och stöd i utformning av stommen till manuskriptet.

\section{Students' mathematical reasoning and beliefs in non-routine task} solving (Inskickad för publicering, februari 2015) - Jonas Jäder, Johan Sidenvall \& Lovisa Sumpter

Den tredje och sista studien är ett samarbete där undertecknad tillsammans med JS jobbat med urval och datainsamling, samt analys av data med stöd av LS. De tre författarna har tillsammans skrivit manuskriptet. 


\section{Innehållsförteckning}

Förord

Sammanfattning

Abstract

vii

Avhandlingens studier

viii

DEL 1 - KAPPA

1 Introduktion

1.1 Skolans utmaningar

1.2 Möjligheter till lärande

2 Syfte och frågeställningar

3 Bakgrund 7

3.1 Matematiska resonemang 7

3.2 Ett nät av kunskap 8

$\begin{array}{lll}3.3 & \text { Ett ramverk för analys av resonemang } & 14\end{array}$

3.4 Kunskap som en individuell konstruktion i ett socialt samspel 16

3.5 Sociomatematiska normer som en grund för möjligheterna till lärande 16

3.6 Elevers uppfattningar om matematik 22

$\begin{array}{lll}3.7 & \text { Lärobokens betydelse } & 23\end{array}$

4 Metodöverväganden 27

4.1 Kategorisering av resonemang i läromedelsuppgifter 27

4.2 Kategorisering av elevresonemang 29

4.3 Att studera elevers uppfattningar 31

5 Om studierna och deras resultat $\quad 32$

5.1 Sammanfattning av studie $1 \quad 32$

5.2 Sammanfattning av studie 2

$\begin{array}{lll}5.3 & \text { Sammanfattning av studie } 3 & 34\end{array}$

6 Diskussion $\quad 35$

6.1 Klassrumsarbetet $\quad 35$

6.2 Läromedlen och läromedelsanvändningen $\quad 40$

$\begin{array}{lll}6.3 & \text { Sammanfattande slutsatser } & 43\end{array}$

$\begin{array}{lll}6.4 & \text { Fortsatt forskning } & 44\end{array}$

$\begin{array}{ll}\text { Referenser } & 46\end{array}$ 
DEL 2 - STUDIERNA

Studie 1: Reasoning requirements in school mathematics textbooks: an analysis of books from 12 countries

Studie 2: Students' reasoning in mathematical textbook task-solving

Studie 3: Students' mathematical reasoning and beliefs in non-routine task solving 


\section{DEL 1 - KAPPA}





\section{Introduktion}

\subsection{Skolans utmaningar}

Utbildningsväsendet och skolan är viktiga institutioner för att de så tydligt omfattar en stor del av befolkningen och dessutom en del av befolkningen som har stor potential att forma framtiden. Schmidt et al. (2001) beskriver att dåtiden formar våra skolor, och våra skolor formar framtiden. Skolan står ständigt inför stora utmaningar för att på bästa möjliga sätt kunna stötta elever i deras strävan efter att nå sin fulla potential. För att kunna se en helhet $\mathrm{i}$ utbildningen behöver densamma också brytas ned i mindre delar och analyseras i syfte att kunna svar på frågor om vad som görs och vad som behöver förändras och på vilket sätt.

Ett övergripande tema för de tre studier som ingår i denna avhandling är förmågan att resonera matematiskt. Jag har utgått från en definition av matematiska resonemang (Lithner, 2008) där resonemanget kategoriseras baserat på vilken typ av kunskap som används. Medan ett imitativt resonemang baseras på memorerade algoritmer eller imitation av en lösning, kräver ett kreativt matematiskt resonemang att en lösning skapas helt eller delvis utan ett sådant stöd. För snart hundra år sedan poängterade Dewey (1929) att skolundervisningen plågas av en strävan efter snabba svar. Fortfarande kan liknande tendenser ses i matematikutbildningen (Rezat \& Strässer, 2012). En av de avgörande anledningarna till inlärningssvårigheter avseende matematik är att utantillinlärning är basen i matematikundervisningen för många elever (Hiebert, 2003). Lithner och Palm (2010) beskriver en elevs skolgång som, bland annat, ett ackumulerande av algoritmer som till slut blir för många för eleven att hantera. Analyser av läromedel från flera olika länder har påvisat att det finns brister i vad eleverna får möta i bokens presentationer respektive uppgifter, avseende en bred matematisk kompetens, där såväl procedurer som till exempel problem lösning och resonemang får utrymme. (Fan \& Zhu, 2007; Vincent \& Stacey, 2008). Procedurella kunskaper är väsentliga i matematiken och är basen för mycket problemlösning, men avtar i värde om den alltför sällan knyts till ett sammanhang. Boaler (1998) förtydligar detta genom att dra slutsatsen att många elever som besitter utantillkunskaper inte klarar av att överföra denna kunskap till nya situationer och att lösa, för dem nya problem. Schoenfeld (2012) beskriver en situation där det, redan tidigt i ett barns utbildning byggs upp en kultur som baseras på att lösa uppgifter så snabbt och smidigt som möjligt med hjälp av inövade algoritmer. Inom en begränsad kontext och mer kortsiktigt kan "rules without reasons" (Skemp, 1976), grundlösa regler vara välmotiverat. Men om å andra sidan en förståelse för en större helhet finns skapas utrymme för en större flexibilitet (Skemp, 1976). Exempelvis har det visat sig mer värdefullt och effektivt att skapa en förståelse för de procedurer som används i matematiken än att lära sig utantill (Hiebert, 2003). Det är oerhört viktigt att mer inkluderas i termen lärande än bara att "komma ihåg". Distinktionen mellan procedurer och ett mer 
resonerande arbetssätt kan exemplifieras med hjälp av ett exempel tidigare presenterat av Lithner (2003).

En elev frågar sin lärare om $a^{5} \cdot a^{3}=a^{15}$. Han berättar att han minns att beräkningen har något att göra med att adderas eller multiplicera exponenterna, men att han inte minns vilket av räknesätten som är det korrekta.

Exemplet visar hur en algoritmisk syn på matematiken och ett procedurellt tillvägagångssätt kan hämma eleverna i deras utveckling. En fråga som bör ställas i relation till exemplet är, varför eleven, istället för att försöka erinra sig en specifik algoritm, inte beaktar de grundläggande egenskaperna hos potenstal. I detta fall hade det räckt att eleven förstod och beaktade att $\mathrm{a}^{\mathrm{m}}$ bara är ett mer smidigt sätt att representera en upprepad multiplikation $\mathrm{a} \cdot \mathrm{a} \cdot \mathrm{a} \cdot \mathrm{a} \cdot \mathrm{a} \cdots \mathrm{a}$ med $\mathrm{m}$ faktorer. Med hjälp av denna förståelse och ett resonemang kring antalet faktorer i $a^{5}$ respektive $a^{3}$ kan en slutsats dras där $a^{5} \cdot a^{3}=a^{8}$. Ytterligare ett exempel som jag stött på i min roll som lärare är då elever använder sig av en algoritm som inte är applicerbar i det aktuella sammanhanget.

I läroboken återfinns uppgiften att räkna ut $-5-3$. En elev försöker använda kalkylatorn i sin mobiltelefon för att lösa uppgiften. Tyvärr kan inte mobilen hantera negativa tal så bra, och han lyckas inte få fram något svar. Istället erinrar han sig att "minus och minus blir plus", och att svaret med andra ord borde bli 8 .

Eleven i exemplet minns en algoritm för multiplikation av negativa tal. Tyvärr har algoritmen inte något stöd av en djupare förståelse hos eleven vilket leder till att eleven använder den i fel sammanhang. Att eleven till synes verkar ha en svag taluppfattning medför dessutom att svaret accepteras. Hiebert (2003) anser det sannolikt att en elev mer troligt minns en procedur om han också förstår hur den fungerar. Dessutom ökar då sannolikheten att eleven kan applicera proceduren i nya sammanhang.

Forskning har visat att ett medvetet arbete med matematiska förmågor såsom problemlösning, kommunikation, modellering och resonemang krävs för att kunna behärska matematik (Hiebert, 2003). Detta har också satt sina spår i riktlinjer och styrdokument såväl i Sverige som i andra delar av världen (Boesen et al., 2014) som numera tydligt betonar vikten av en bred matematisk kompetens och vilka förmågor som krävs för att detta ska uppnås. Att behärska matematik innebär att inneha en rad förmågor (Niss, 2003). Niss (2003) beskriver att en individ kan inneha en förmåga till viss del, och i relation till ett visst matematiskt innehåll. Det finns två aspekter av de matematiska förmågorna, den analytiska vilket innebär att en viss förståelse skapas, och en produktiv där fokus är på produkten av ett matematiskt arbete (Niss, 2003). Således har en förändrad målbild inom matematikutbildningen vuxit fram, där hänsyn tas till en helhet som inkluderar flera förmågor som tillsammans bygger upp en matematisk 
kompetens. De förmågor som nämns i den svenska ämnesplanen för matematik på gymnasiet är: begreppsförståelse, procedurhantering, problemlösning, matematisk modellering, resonemangsförmåga, kommunikation och slutligen att kunna relatera matematiken till hur den används inom olika områden, det vill säga relevansförmågan. De olika förmågorna är både relaterade till varandra och ibland överlappande (Niss, 2003). Skolverket (2011a, s. 8) skriver:

Kunskap är inget entydigt begrepp. Kunskap kommer till uttryck i olika former - såsom fakta, förståelse, färdighet och förtrogenhet - som förutsätter och samspelar med varandra. Undervisningen får inte ensidigt betona den ena eller den andra kunskapsformen.

Citatet visar på komplexiteten i kunskapsbegreppet och på nödvändigheten av att diskutera vad matematisk kunskap är och hur den byggs upp. En del av matematikens berättigande som skolämne formuleras i kommentarsmaterialet till ämnesplanen i matematik, av Skolverket (2011b) på följande sätt:

Förutom att elever i skolan får en direkt tillämpning av ett matematikinnehåll som behandlas, får de också möjlighet att upptäcka matematikens egenvärde.

Det vill säga, såväl att träna sig i logiskt tänkande, som att kunna applicera procedurer i verkliga problemlösningssituationer är en drivkraft i ämnet. Mål och kunskapskrav som uttrycks i olika styrdokument så som läroplaner och kurs- eller ämnesplaner blir levande i klassrummen och i skolan. Det är här som utbildningen genomförs och elevernas resultat mäts. Den svenska skolinspektionen har uppmärksammat att lärare ofta lämnas att tillsammans med sina kollegor på skolan tolka nya styrdokument (Boesen et al., 2014). Vidare har det visat sig att en stor majoritet av skolorna inte i tillräcklig utsträckning undervisar mot målen i styrdokumenten (Boesen et al., 2014). Förmågor så som resonemang, problemlösning och kommunikation hamnar i skymundan. Lithner (2003) oroar sig för en situation som är alltför obalanserad och där få möjligheter att lära sig resonera matematiskt gör det svårare för eleverna att utveckla en förståelse. Även Schoenfeld (2012) betonar vikten av en bredare syn på vad som ska betraktas som matematik. Han inser att givetvis måste vissa regler och procedurer bemästras, men att samtidigt krävs det ett arbetssätt i klassrummen där tonvikt läggs även på att göra antaganden, utforska och på att skapa djupare förståelse för matematiken. Forskning har också visat att en undervisning som syftar till att stärka en bred matematisk kompetens, där såväl procedurer som en förståelse för dessa är möjlig (Hiebert, 2003). Detta innebär en undervisning som bereder eleverna möjligheter att jobba med förmågor såsom resonemang, problemlösning, begreppsförståelse och modellering. Hiebert och Lefevre (1986) motiverar en breddad målbild och en strävan efter en ökad förståelse för matematiken med att de nödvändiga procedurerna blir mer användbara om de kan relateras till en större helhet. På så sätt kan också procedurerna användas i flera olika kontexter och inte heller i alla lägen användas som memorerade algoritmer utan snarare med hjälp av matematiska resonemang. En större förståelse för helheten ökar också möjligheten för 
eleverna att använda sig av flera procedurer och begrepp i en och samma problemlösningssituation och koppla samman dessa (Hiebert \& Carpenter, 1992).

\subsection{Möjligheter till lärande}

Ett av de starkaste didaktiska forskningsresultaten kan synas självklart, men är så oerhört viktigt att det ändå bör betonas. Elever lär sig det de får en möjlighet att lära sig (Hiebert \& Grouws, 2007). På samma sätt som att det behövs en cykel för att kunna lära sig cykla, behöver eleverna $\mathrm{i}$ våra skolor möta specifikt kursinnehåll och ges möjligheten att träna på specifika matematiska förmågor för att lära sig det som förväntas av dem. Möjligheter till lärande är inte det samma som att få undervisning eller att exponeras för, utan något mer komplext (Hiebert \& Grouws, 2007). Till exempel är det svårt att påstå att en nyfödd bebis som får en cykel och lite instruktioner också har fått en möjlighet att lära sig cykla. Utifrån samma resonemang bör en elev innan han kan få en möjlighet att lära sig lösa ekvationer känna sig trygg med begrepp som till exempel variabler och likhetstecknets betydelse. Men med adekvata förkunskaper är just möjligheterna till lärande, i form av någon typ av exponering, en nödvändighet för lärande. Möjligheter till lärande kan användas som ett mått på huruvida elever haft möjligheten att träna upp en viss förmåga eller öva på ett visst matematiskt innehåll (Husen, 1967, citerad i Burstein, 1993). Detta innebär att utbildningssystemet och skolan, inklusive lärare och elever måste skapa möjligheter för lärande. Utifrån en elevs förkunskaper behöver alltså lärsituationer skapas så att möjligheter att lära sig ett specifikt ämnesinnehåll eller att träna en specifik matematisk förmåga ges. För som Hiebert (2003) skriver är det inte eleverna som är problemet, de kan utvecklas mer om ökade möjligheter till lärande skapas.

Möjligheterna till lärande beror på en mängd olika faktorer, så som läroboken, en lärares genomgångar, tidsutrymme, elevers begränsande och stöttande uppfattningar om matematik eller om undervisningen bedrivs utifrån varje elevs förkunskaper eller inte. Den här avhandlingen diskuterar några av dessa faktorer. Den första studien presenterar en undersökning där läromedel, som en väsentlig del av det som eleven möter i skolan, har analyserats utifrån vilka möjligheter till matematiska resonemang de erbjuder eleverna. Den andra studien visar på vilket sätt elever arbetar med läroboksuppgifter och vilka matematiska resonemang som faktiskt används av eleverna i klassrummet. Slutligen undersöker den tredje studien vilka uppfattningar om matematik och matematiska resonemang och problemlösning elever har och på vilket sätt dessa kan kopplas samman med elevernas agerande med avseende på matematiska resonemang. Läromedel, deras uppgifter och hur dessa används, samt elevernas egna uppfattningar är några av många faktorer som påverkar vilka reella möjligheter till lärande som skapas och kan således bidra till en bild av vad som görs i skolan idag (Rezat \& Strässer, 2012).

Att påverka möjligheterna till lärande kan ske på flera olika plan, såväl på systemnivå, till exempel genom utformningen av styrdokument och standards, som på en mer praxisnära nivå 
på skolor och ännu mer specifikt då en undervisning implementeras i klassrummet. The International Association for the Evaluation of Educational Achievement (IEA) har i Trends in International Mathematics and Science Study, (TIMSS) diskuterat möjligheterna till lärande med hjälp av tre begrepp i relation till läroplanen (Mullis, Martin, Ruddock, O'Sullivan \& Preuschoff, 2009). Dessa är den avsedda, den genomförda samt den uppnådda läroplanen. Med den avsedda läroplanen menas det som finns skrivet i styrdokument såsom exempelvis ämnesplanen för matematik. Detta är alltså en läroplan som existerar främst på en systemnivå. Den genomförda läroplanen är det som presenteras för eleverna i skolan och innefattar till exempel lärares och läroboksförfattares kommunikation med eleverna. En avsedd läroplan hanteras av en rad källor vars hantering får en stor betydelse för hur den faktiskt genomförs. En källa såsom läroboken kan i denna mening betraktas som en potentiellt genomförd läroplan (Schmidt et al., 2001). Trots att läroboken används på olika sätt i olika miljöer och av olika lärare och elever så syns en tydlig och stark influens från läroboken i den genomförda läroplanen (Rezat och Strässer, 2014). I såväl den avsedda som den genomförda läroplanen kan möjligheterna till lärande mätas som antingen närvarande eller frånvarande eller utifrån den betoning som ges det specifika lärandet (Floden, 2002). Slutligen finns en uppnådd läroplan som är det som faktiskt når varje enskild elev i form av till exempel kunskap (Schmidt et al., 2001). Tydliga distinktioner kan således göras mellan vad som avses med, vad som genomförs av och vad som uppnås av en läroplan. För att komma så nära det verkliga lärandet som möjligt blir det intressant att studera hur en läroplan genomförs snarare än hur den är skriven (Floden, 2002). Det är inom strukturen för skolans lektioner som möjligheter till lärande skapas men även begränsas (Hiebert \& Carpenter, 1992). Lärmiljön påverkas av ett flertal faktorer. Att lärare och elever tillsammans bygger upp denna miljö är både en logisk konsekvens av och en orsak till hur matematiklektionerna i skolan ser ut (Lampert, 1990).

Här, i den introducerande delen av avhandlingen, kappan, är mitt främsta syfte att lyfta fram på vilka gemensamma grunder de tre studierna är gjorda. För att möjliggöra en diskussion kring möjligheterna till lärande krävs en bild av vad matematisk kunskap består av och även hur denna kunskap byggs upp. Som en del av matematisk kunskap finns förmågan till matematiska resonemang vilket är huvudfokus i avhandlingens tre studier. Därför fördjupas diskussionen kring kunskap utifrån just matematiska resonemang. Detta leder diskussionen vidare till vilken lärmiljö som skapas i skolor och klassrum. Diskussionen kring lärmiljön har två utgångspunkter, nämligen vilken påverkan läromedel respektive elevers uppfattningar har på miljön som skapas och på lärandet. Därefter beskriver jag på vilka grunder de olika metodologiska besluten tagits och sammanfattar de tre studierna var för sig. Studierna tar avstamp i tidigare forskningsresultat som diskuterar vad som är centralt för en god matematikutbildning. Utifrån forskning kring god undervisning och den nulägesbeskrivning som de tre studierna tillsammans med andra studier bidrar med kan en diskussion kring tänkbara förändringar i skolan och dess struktur initieras. I kappan önskar jag främst att ha 
den svenska skolan i sikte och skriver därför också på svenska. Data till avhandlingens tre studier har också samlat från den svenska gymnasieskolan. Utöver detta består dessutom den första studien av en analys av matematikläromedel från ytterligare elva länder.

\section{Syfte och frågeställningar}

Det övergripande syftet med studierna som ingår i denna avhandling är att studera och skapa en större förståelse för vad som sker i skolan idag med avseende på matematiska resonemang, och vilka möjligheter till att lära sig att resonera matematiskt eleverna får. Detta sker genom att undersöka flera aspekter som potentiellt påverkar elevers möjlighet till lärande. Elevers läromedel används som en indikator på möjligheterna till lärande och analyseras både utifrån vilka krav uppgifterna ställer på eleverna och utifrån hur eleverna använder läroboken på lektionstid. Då sättet som elever agerar på i problemlösningssituationer visat sig vara länkat till deras uppfattningar om ämnet undersöks även elevers uppfattningar om matematik i relation till de matematiska resonemang som används för att ytterligare vidga bilden av vilka möjligheter till att lära sig att resonera matematiskt som eleverna får. Mer specifikt är frågeställningarna $\mathrm{i}$ de tre studierna enligt nedan. För de mer tekniska forskningsfrågorna hänvisas till respektive studie.

Studie 1: Reasoning requirements in school mathematics textbooks: an analysis of books from 12 countries.

- I vilken utsträckning räcker det med imitativa resonemang för att lösa uppgifterna i matematikläromedel från 12 olika länder, och vilka möjligheter till lärande med avseende på olika typer av resonemang erbjuder böckerna.

Studie 2: Students' reasoning in mathematical textbook task-solving.

- På vilket sätt angriper elever olika typer av läroboksuppgifter, med avseende på olika typer av resonemang, och i vilken utsträckning lyckas de med sina lösningar?

Studie 3: Students' mathematical reasoning and beliefs in non-routine task solving.

- Vilka uppfattningar om matematik uppvisar eleverna i relation till det resonemang som används då de löser icke-rutinuppgifter? 


\title{
3 Bakgrund
}

För att kunna genomföra studierna och skapa en förståelse för vad matematiska resonemang kan innebära för matematikundervisningen vill jag nu presentera en bild av vad matematisk kunskap är och hur den kan byggas upp. Vidare önskar jag placera denna kunskapsutveckling i ett större socialt sammanhang där den rådande klassrumskulturen ligger till grund för en elevs möjligheter till lärande. Lärmiljön påverkas av en mängd faktorer, varav läroboken är en. Läroboken diskuteras utifrån såväl dess betydelse i undervisningen, som sin utformning och hur den används i klassrummet.

\subsection{Matematiska resonemang}

Ball och Bass (2003) beskriver det som att en diskussion om matematisk förståelse blir meningslös utan en tonvikt på resonemang. De beskriver matematiska resonemang som såväl ett mål som ett medel för att nå denna förståelse. Ett matematiskt resonemang kan användas för att förklara eller bevisa en kunskap. Men matematiska resonemang kan även användas för att utforska ny matematik och skapa förståelse för nya begrepp eller procedurer och bygga ny kunskap. För att skapa förståelse för någonting och för att även kunna använda detta i olika kontexter krävs resonemang. Genom att se detta i ett socialt sammanhang definierar Bauersfeld (1980) resonemang som förmågan att motivera val och slutsatser genom argumentation som baseras på logik och matematisk kunskap. I linje med Bauersfeld definieras resonemangsförmågan av Skolverket (2011b) på följande sätt:

\begin{abstract}
Resonemangsförmågan innebär att kunna föra matematiska resonemang som involverar matematikens begrepp, metoder och utgör lösningar på problem och modelleringssituationer. Att föra ett resonemang innefattar även att själv och tillsammans med andra till exempel testa, föreslå, förutsäga, gissa, ifrågasätta, förklara, finna mönster, generalisera, argumentera. Det innefattar även att kunna formulera och allmänt undersöka hypoteser samt genomföra bevis i tal och skrift. Detta inkluderar att uppmärksamma betydelsen av och kunna redogöra för de bärande idéerna i ett matematiskt bevis och inse skillnader mellan gissningar och välgrundade påståenden.
\end{abstract}

Att resonera innebär alltså att flera andra förmågor införlivas i en process för att kunna dra önskade slutsatser. Jag har för syftet med dessa tre studier valt att använda en definition av resonemang som enligt Lithner (2008) är utfallet av den tankebana som antagits för att formulera påståenden och dra slutsatser. Definitionen gör det möjligt att kategorisera resonemang utifrån vilken typ av kunskap som används. Som en bakgrund till definitionen av matematiskt resonemang blir det därför relevant med en diskussion kring matematisk kunskap. I följande avsnitt presenteras en modell för hur matematisk kunskap kan betraktas och för hur denna kunskap byggs. Kunskapsmodellen fungerar också som bas för att introducera det ramverk för kategorisering av matematiska resonemang (Lithner, 2008) som använts i avhandlingens samtliga studier. 


\subsection{Ett nät av kunskap}

Resonemangsförmågan beskrivs av skolverket (2012) som vilandes på en konceptuell grund och dessutom som ett verktyg för att utveckla förståelsen för det matematiska innehållet och dess relation till andra områden. Vad som kan avses med konceptuell kunskap fångas av den metafor som Hiebert och Lefevre (1986) presenterar och benämner ett nät av kunskap (se figur 1 för exempel). Nätet är rikt på sammankopplande relationer och fakta. I noderna finns till exempel grundförståelsen för matematiska objekt. När en större förståelse skapas framträder hur dessa matematiska objekt relaterar till varandra, och ett nät formas och växer sig starkare. Ett nytt objekt kan införlivas i nätet för att vidga detsamma, likväl som att två mindre nät kan sammanfogas till ett större med hjälp av en sammankopplande relation. När så fler relationer skapas mellan de bägge nätdelarna växer sig det stora nätet starkare. En konceptuell kunskap kan med andra ord inte bestå av en enskild faktauppgift, utan är snarare ett förhållande mellan faktauppgiften och annan information.

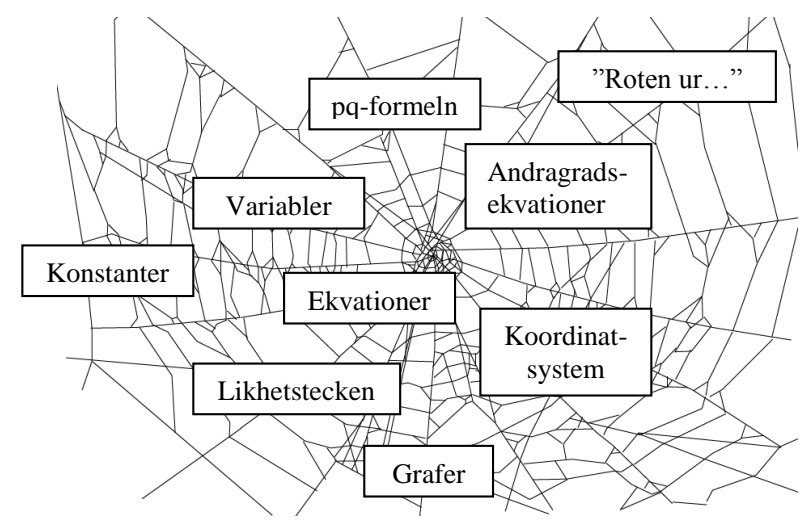

Figur 1. Exempel på ett nät av kunskap, med kopplingar som bygger upp en konceptuell kunskap.

Procedurell kunskap å andra sidan beskrivs som bestående av det formella matematiska språket och algoritmer (Hiebert \& Lefevres, 1986). Detta inkluderar till exempel en medvetenhet om de matematiska symbolerna och om hur man hanterar dem, samt regler, procedurer och algoritmer som kan användas för att lösa matematiska uppgifter (Hiebert \& Lefevres, 1986). Distinktionen mellan de två typerna av kunskap kan exemplifieras genom att betrakta ett barn som blir ombedd att tala om hur många leksaker det ligger på golvet. Hon inleder räknandet; 1, 2, 3... och slår slutligen fast att det ligger sju leksaker på golvet. Uppräkningen kan ses som en procedur bestående av att uttrycka tal i en förutbestämd ordning. I och med att uppräkningen slutar på sju drar barnet slutsatsen att svaret på frågan är just sju leksaker. Men när samma fråga ställs en gång till visar det sig att den procedurella kunskapen inte är länkad till den konceptuella, i form storhet eller antal, då barnet snarare än att direkt svara sju, återigen börjar räkna för att kunna besvara frågan. En procedurell kunskap kan givetvis även den vara svagare eller starkare utvecklad. I följande exempel visas på en situation där denna skillnad synliggörs. 
En elev som tidigare i kursen visat procedurella kunskaper löser ekvationen $3 x+6=15$ genom algoritmen som går ut på att "flytta" termer, koefficienter och delar av rationella uttryck från ena ledet till det andra. En metod som innebär att exempelvis en positiv konstantterm kan elimineras från ena ledet genom en subtraktion som utförs i bägge leden för att behålla likheten. Detta tillvägagångssätt hanteras dock inte sälla per automatik som att "flytta" termen med omvänt tecken till andra ledet. Dock använder eleven i detta fall algoritmen på ett felaktigt sätt då han inleder arbetet genom att "flytta" koefficienten (3:an) först, på ett felaktigt sätt, utan att ta hänsyn till konstanttermen 6. I och med att metoden baseras på att just flytta innebär det att eleven delar 15 med 3, och får $x+6=5$ vilket sedan leder till svaret $x=-1$. Eleven hade med en tryggare procedurell kunskap kunnat börja med att flytta 6:an och får $3 x=9$ efter förenkling. Nästa steg för eleven blir då att flytta även koefficienten 3 och på så sätt slutligen få svaret $\mathrm{x}=3$.

I detta fall är det dessutom uppenbart att eleven hade varit hjälpt av en större konceptuell förståelse där exempelvis algoritmen för ekvationslösning var kopplad till en förståelse för likhetstecknet, och till metoden giltighet. Förståelsen kan enligt Gravemeijer och van Galen (2003) skapas genom att eleverna själva, utifrån flera problemsituationer får möjligheten att jämföra lösningsmetoder och generalisera. Ett problem med den procedurella kunskapen då den isoleras är således att en större mängd information måste memoreras. Inte heller blir det självklart att bygga upp matematiska modeller för att lösa problem om inte procedurerna kan kopplas till en större helhet och på så sätt också användas i olika situationer. Ett exempel på detta är en elev som jobbar med en uppgift där kostnaden för att gå på två olika gym, A och B, jämförs. Uppgiften består i att undersöka hur många gymbesök det krävs för att gym A ska vara fördelaktigt att gå på.

Det ena gymmet, gym A har en årsavgift på $1500 \mathrm{kr}$ och därefter betalar man 30 kr/besök. På det andra gymmet, gym B kostar ett besök 75 kr. Eleven, som enbart lärt sig algoritmen för att lösa ekvationer och en definition för variabel får svårt att lösa uppgiften då det krävs att en matematisk modell skapas, där exempelvis $\mathrm{y}=1500+30 \mathrm{x}$ likställs med $\mathrm{y}=75 \mathrm{x}$, eller där de bägge ekvationerna representeras som grafer. Han frågar läraren om hjälp som också visar en möjlig väg framåt genom att skriva ner de bägge ekvationerna åt eleven. Återigen fastnar dock eleven. Denna gång på grund av en bristande förståelse för att kostnaden för gym A och B kan likställas genom att jämföra respektive uttryck med variabeln $\mathrm{x}$. Läraren kommer återigen till eleven och visar att $1500+30 \mathrm{x}$ kan likställas med $75 \mathrm{x}$ och att då en ekvation som kan lösas för $\mathrm{x}$ skapas. Tyvärr har eleven inte tidigare stött på ekvationer med $\mathrm{x}$ i bägge leden och måste ännu en gång fråga läraren om hjälp, som nu förklarar för eleven att 30x kan "flyttas till andra sidan" precis som konstanttermer. Då har eleven efter förenkling ekvationen $1500=$ $45 \mathrm{x}$ framför sig, som han löser med hjälp av sedan tidigare bekant algoritm. Han svarar $x=33,33$ på uppgiften, noterar att facit har avrundat felaktigt till 34, och går vidare. 
I exemplet visas en situation då den algoritmiska kunskapen återigen inte räcker till för att lösa ett matematiskt problem. I detta fall orsakar bristen både att en modell inte kan skapas, men också att proceduren utan stöd från en större helhetsförståelse inte stöttar en delvis ny problemformulering. Genom att inte heller underbygga sitt svar med en koppling till uppgiftens kontext, indikeras ytterligare att eleven inte naturligt kopplar samman sin algoritmiska kunskap med en större förståelse för en helhet. Att istället svara att vid 33 besök eller färre på gymmet lönar det sig att gå på gym B, men då antalet överstiger 33/år så är det mer ekonomiskt att gå på gym $\mathrm{A}$, visar att mer än en procedur har använts för att lösa problemet. I exemplet visas också den betydelse en lärare kan ha för en elevs lärande. Sättet på vilket lärare handleder elever återkommer jag till i diskussionen.

Skemp (1976) beskriver två typer av förståelse som särskiljs genom att man antingen vet hur något genomförs, eller vet såväl hur som varför någonting genomförs. Skemp (1976) åskådliggör skillnaden mellan de två olika typer med hjälp av en metafor baserad på två personer som flyttar till en ny stad. De bägge personerna bekantar sig på varsitt sätt med stadens omgivningar. Jag beskriver i det följande en metafor fritt efter Skemp (1976). Låt oss börja med att betrakta person 1 som lär sig vägen från sin nya bostad till sitt jobb, och från bostaden till affären och till motionsspåret. Han lägger på minnet höger respektive vänstersvängarna och i vilken ordning dessa genomförs. När detta väl är gjort nöjer han sig. Han har nu memorerat tre stycken färdvägar. Person 2 lär sig även han vägen från bostaden till jobbet, till affären och till motionsspåret. Relativt omgående blir dock personen intresserad av att även kunna gå via affären hem från jobbet någon dag. Under sina initiala promenader reflekterar han över platsernas inbördes läge i relation till varandra. Person 2 börjar skapa en slags mental karta över staden där även en potentiell väg från jobbet till affären finns representerad, trots att han egentligen aldrig ännu gått den vägen. På detta sätt lyckas person 2 utforska även andra delar av staden och stärker bilden av den mentala kartan han skissat. Med tiden kopplas allt fler punkter i staden samman vilket möjliggör att han till exempel kan ta en löprunda innan jobbet en morgon utan att behöva åka hem emellan, eller ta en annan väg till jobbet dagen då ett vägarbete begränsar framkomligheten. Han kan således konstruera ett nästan oändligt antal resvägar inom staden. Person 1 som inte skapat en mental karta över staden tvingas dagen då ett vägarbete hindrar hans väg till jobbet ringa en arbetskamrat för att få en alternativ vägbeskrivning. Då person 2 ställs inför samma problem lyckas han tack vare sin mentala karta själv konstruera en alternativ resväg. Att fråga om hjälp är givetvis i sig inte att förakta, men den flexibilitet som en mental karta erbjuder och det faktum att faktiskt få eller inga vägbeskrivningar då heller behöver memoreras talar för att den mentala kartan kan underlätta. Det som person 1 bär med sig kan jämföras med den information man kan få ut om man söker på vägbeskrivningen mellan två städer i Google Maps. Person 1 har i detta fall ett flertal sådana vägbeskrivningar med hänvisningar till höger- och vänstersvängar och avståndsangivelser. Person 2 å andra sidan bär istället för dessa vägbeskrivningar med sig den karta man också kan ta fram på Google Maps och som innehåller information om platsers inbördes relation till varandra. Skemp (1976) skiljer på den undervisning som syftar till att 
skapa en mental karta och den som istället ger en detaljerad vägbeskrivning. Parallellt till Skemps (1976) metafor beskriver jag nedan två exempel på hur jag själv som gymnasielärare i matematik valt att presentera begreppet andragradsekvationer för mina elever. Dessa två exempel illustrerar hur synen på kunskap hos mig som lärare också påverkar de möjligheter till lärande av olika typer av kunskap som eleven får. I den första undervisningssituationen står den algoritmiska kunskapen i centrum medan den kunskap som relaterar begrepp och procedurer till varandra för en djupare förståelse får större utrymme $\mathrm{i}$ den andra undervisningssituationen.

Ett sätt att introducera begreppet andragradsekvationer som jag vid flera tillfällen använt mig av är att tillsammans med eleverna lösa ett antal typekvationer på tavlan och bygga upp en bulk av mallar för eleverna att förhålla sig till då de senare går vidare till att lösa läroboksuppgifter. Inkluderat i en sådan presentation finns ofta också ett tillämpat problem av typen där en till exempel kulstöts längd ska beräknas, där kulbanan beskrivs med hjälp av en andragradsfunktion.

Jag har även inlett en diskussion kring andragradsekvationer genom att först diskutera likheter och samband i allmänhet och också kopplat dessa diskussioner till grafiska representationer. Här har också funnits möjligheter att introducera parabler som beskriver exempelvis kaströrelser. Utifrån denna bas har jag sedan fortsatt diskussionen genom att introducera ett exempel på en kaströrelse i form av exempelvis en handbolls bana, $y=1,75+0,8 x-0,04 x^{2}$. I detta skede får eleverna $\mathrm{i}$ uppgift att undersöka hur långt från mål man bör stå för att pricka ribban med en handboll. Många elever i klasserna brukar då försöka skissa bollbanan i ett koordinatsystem och därifrån dra sina slutsatser. Några jobbar mer algebraiskt och ställer upp en ekvation där bollbanan $1,75+0,8 x-$ $0,04 x^{2}$ likställs med ribbans höjd över marken 2 meter. Eleverna finner snart ett behov av en metod att hantera den andragradsekvation som skapats. I detta skede brukar jag finna det lämpligt att visa eleverna den så kallade pq-formeln. För att knyta ihop diskussionen finns ett behov av att få ett antal punkter tydliggjorda för eleverna. En av dessa är att det är möjligt att finna två svar på den ställda frågan. I sammanhanget brukar jag då försöka lyfta fram exempel på såväl grafiska som algebraiska lösningsmetoder som visar på detta. En ytterligare punkt som jag i en sådan undervisningssituation försöker förmedla är det gränssnitt som finns mellan det matematiska och den specifika kontexten som handbollens bana och ribban utgör. Vi samtalar kring betydelsen av att förflytta sig mellan den matematiska modellen och verkligheten och resonerar kring hur denna förflyttning kan ske. I och med detta upplägg har också alla elever fått se såväl en algebraisk metod, pqformeln, som en grafisk metod för att lösa problemet med.

Eleverna i det första exemplet kommer sannolikt bli goda ekvationslösare och också lyckas lösa många av de ekvationer av procedurkaraktär de stöter på i skolan. Det är däremot mer osäkert om det också stöttar en djupare förståelse för när detta kan tänkas vara användbart och modelleringar med hjälp av ekvationer i olika sammanhang. I den andra undervisningssituationen används det som Sfard (1991) beskriver som "matematikens dubbla natur" i och med att begreppet ekvation får en mening med hjälp av procedurer för att lösa andragradsekvationer, samtidigt som begreppet också kopplas till andra begrepp och får en 
innebörd på den större matematiska kartan. Eleverna engageras i en problemlösande aktivitet och precis som Hiebert et al., (1996) uttrycker det så är det slående här inte hur eleverna löser ett extremt svårt problem, eller att de visar på enastående förmågor, utan snarare att eleverna engagerades $\mathrm{i}$ sann problemlösning $\mathrm{i}$ något som annars riskerar att vara en rutinaktivitet. Hiebert och Carpenter (1992) betonar att undervisningen måste sträva efter att eleverna ska bygga relationer mellan matematiska begrepp och att begrepp och procedurer inte ska hanteras som enskilda bitar information utan införlivas i den mentala kartan, kunskapsnätet som eleverna bygger. Såväl procedurell som konceptuell kunskap krävs för en god matematisk kompetens (Hiebert, 2003). Kopplingarna mellan exempelvis två begrepp baseras på likheter och skillnader (Hiebert \& Carpenter, 1992). Genom att skapa en större förståelse för procedurerna kan också antalet procedurer minskas. Till exempel blir det inte nödvändigt att minnas formlerna för hur arean av varje enskild figur beräknas om en djupare förståelse för areabegreppet finns. Att en rektangel har arean basen (b) höjden (h) blir uppenbart, liksom att då formeln för triangelns area är $b \cdot h / 2$. Även parallelltrapetsens och parallellogrammets area följer då naturligt.

Att genom modeller försöka att beskriva kunskap och en lärandeprocess innebär naturligtvis att generalisera och att göra förenklingar. Syftet med att utifrån beskrivningen av olika typer av kunskap bygga upp en modell för samspelet mellan konceptuell och procedurell kunskap är att tydliggöra väsentliga aspekter av lärprocessen. Kunskapsnätet vidgas på så sätt med införlivandet av nya processer och nya matematiska objekt som kopplas till det existerande nätet. Hiebert och Carpenter (1992) definierar förståelse som att ett matematiskt begrepp eller en procedur har införlivats i ett större nätverk med andra begrepp och procedurer. Djupet av förståelse kan beskrivas med antalet kopplingar till andra begrepp och procedurer, och hur dessa kopplingar skapats. I den beskrivna modellen tas en tydlig hänsyn till den förförståelse som finns, och vilken kunskap som kan användas som bas i kunskapsutvecklingen. En kunskap som sedan tidigare införlivats i kunskapsnätet bidrar på ett annat sätt än en isolerad förförståelse för exempelvis en viss, enskild procedur (Hiebert \& Carpenter, 1992).

Utvecklad kunskap kan karakteriseras som en förändring i nätet. Antingen förtätas nätets utseende utifrån de nya kopplingar som tillkommer, eller så vidgas det då nya begrepp, procedurer kopplas till det existerande nätet. Dessutom kan två mindre nät kopplas samman i en eller flera punkter för att skapa ett nytt, större nät. Nätet är i ständig förändring. Ibland kan en förändring baseras på en förvirring, där nätet för en stund får en struktur som inte i alla delar är logiskt uppbyggt.

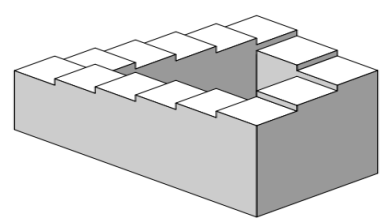

Figur 2. En paradoxal illusion med lokal logik, Penrose trappa. 
Man skulle kunna jämföra ett sådant förvirrat nät med en paradoxal illusion som till exempel Penrose trappa (se figur 2) där logiken finns lokalt men inte i ett större sammanhang, men där den mer omfattande logiken ändå sätts på prov. Förhoppningsvis leder undervisningen till att ett sådant kunskapsnät istället omstruktureras. Innan ny kunskap införlivas i tidigare befäst kunskap kan den skapa ett eget delnät där ett fåtal procedurer och begrepp ryms, som sedan $\mathrm{i}$ sin helhet knyts till det större nätet. Förändringar i ett kunskapsnät kan illustreras med nedanstående exempel där bråkräkning introduceras för en elev.

En elev har en förförståelse för bland annat de hela talen och även för begreppet division och även hur division av heltal kan utföras, det vill säga i elevens kunskapsnät finns det kopplingar mellan heltal och begreppet division samt en algoritm för division. För att urskilja hur starka dessa kopplingar är och vad de är uppbyggda av krävs en hel del efterforskning. På en matematiklektion presenteras eleven för bråkbegreppet och får ett stöd $\mathrm{i}$ att införliva detta $\mathrm{i}$ sitt kunskapsnät genom att koppla det till såväl de hela talen som till division. Inledningsvis ser eleven bråktalen som två objekt, täljare och nämnare som delas med varandra, men med tiden utvecklas en förståelse för hur det rationella talet som sådant också är ett objekt i sin egen rätt, och kan införlivas i kunskapsnätet även med kopplingar till begrepp som procent, och tiondelar, hundradelar och tal i decimalform. Undervisningen går vidare till att addera bråk med gemensam respektive olika nämnare. Återigen relateras dessa nya idéer till det redan befintliga kunskapsnätet, och bland annat till begreppet addition och algoritmer för additionsberäkningar. När eleven sätter sig för att lösa en läroboksuppgift där två bråktal ska adderas stöter han dock på problem. Uppgiften är att beräkna $\frac{1}{4}+\frac{2}{3}$, och eleven använder då delar av de kopplingar han byggt upp för att komma fram till ett korrekt svar. Han adderar täljarna och nämnarna var för sig och kommer fram till $\frac{3}{7}$, jämför det med facit och inser att hans svar är felaktigt. Eleven har i sitt försök att koppla det som undervisningen tar upp till sitt eget kunskapsnät inte helt lyckas skapa tillräckligt med kopplingar utan förlitar sig på någon enstaka koppling mellan heltalen har ser som delar av bråktalen och den förståelse för addition han sedan tidigare har, vilket i detta fall inte är erforderligt. Han provar då att istället skriva om respektive bråk i decimalform och adderar sedan dessa med resultatet och får fram resultatet $0,91666 \ldots$ Återigen jämför han sitt svar med facit och ser att de inte stämmer överens. Denna gång har han använt andra kopplingar i sitt nät och detta på ett välgrundat sätt. Kopplingen mellan tal skrivna i bråkform och tal skrivna i decimalform verkar inte tillräckligt utvecklad för att han ska se sambandet mellan sitt svar och $\frac{11}{12}$, som facit anger som rätt svar. Ytterligare jämförelser mellan de två representationsformerna verkar krävas för att eleven ska se en större helhet.

För att stötta eleven ovan i en strävan efter ett större och stabilare kunskapsnät krävs det att han får en undervisning som beaktar hans förkunskaper och hjälper till att skapa starka kopplingar mellan dessa och de nya begrepp som det undervisas om. För att eleverna ska beredas möjligheter till konceptuell kunskap krävs utmaningar. En utmaning bör vara möjlig för eleven att klara av men ändå befinna sig på den övre delen av den proximala 
utvecklingszonen (Vygotsky, 1978). Den proximala utvecklingszonen beskriver vad en elev kan förväntas lära sig utifrån sina förkunskaper och förutsättningar för stunden. Det innebär att utmaningen som skapas består av något som till viss del är nytt för eleven och som stimulerar upptäckande. Att eleverna själva upptäcker betyder också att de knyter an till sina egna förkunskaper (Hiebert \& Grouws, 2007). Möjligheter till lärande med fokus på en bred matematisk kompetens behöver således vara elevcentrerade och dessutom innehålla utmaningar där mer än utantillkunskaper används (Hiebert \& Grouws, 2007). Detta medför ett behov av en balanserad matematik utbildning där möjligheter ges till elever att jobba med procedurer såväl som resonemang baserade på en konceptuell förståelse.

\subsection{Ett ramverk för analys av resonemang}

Med förståelsen för vilka typer av kunskap som krävs för att skapa en bred matematisk kompetens har jag valt att använda mig av ett ramverk (Lithner, 2008) för kategorisering av olika typer av resonemang som tar hänsyn till om eleven får möjlighet att träna på mer än en procedurell förmåga. Resonemang definieras som utfallet av den tankebana som antagits för att formulera påståenden och dra slutsatser (Lithner, 2008). I resonemang innefattas i och med definitionen även resonemang som inte är baserade på formell logik och bevisföring. Resonemangen kan till och med vara felaktiga, eller baseras på imitation snarare än djupare förståelse. Det centrala är dock att även om de är felaktiga stöttas de av någon form av argument som betraktas som rimliga och meningsfulla av den resonerande. Ramverket möjliggör en mer nyanserad diskussion av den typ av kunskap som eleverna använder och de möjligheter till lärande som detta innebär.

De empiriska studier som ligger till grund för ramverket visar på två huvudkategorier av resonemang. Dessa två benämns kreativa matematiska resonemang och imitativa resonemang. Det finns tre krav på ett resonemang för att kunna kategoriseras som kreativt matematiskt. Ett för uppgiftslösaren nytt resonemang ska föras, strategivalet ska vara medvetet samt motiveras med argument som bygger på relevanta matematiska egenskaper. Viktigt att notera är att ett kreativt resonemang inte nödvändigtvis måste uppfinna något helt nytt, utan snarare att en ibland till synes anspråkslös lösningsmetod har skapats som är ny för uppgiftslösaren (Jonsson, Nordqvist, Lithner \& Liljekvist, 2014). Kreativa matematiska resonemang kan antingen omfatta en större, central, global del av en uppgiftslösning eller enbart en mindre central, lokal del av uppgiftslösningen. Imitativa resonemang å andra sidan passar ofta väl vid arbete med rutinuppgifter, då genomförandet enbart består av att imitera en återkallad eller på annat sätt lättillgänglig algoritm, eller att från minnet producera ett svar på en fråga. I detta fall är det ledtrådar i form av till exempel nyckelord eller mer ytlig karakteristik i uppgiften som vägleder eleven i strategivalet. De imitativa resonemangen kan ytterligare preciseras i underkategorier utifrån på vilket sätt som algoritmen tillgängliggörs (se tabell 1 nedan).

En algoritm definieras här som en instruktion med ett begränsat antal steg som möjliggör att ett svar erhålls för en viss typ av uppgifter (Brousseau, 1997). En algoritm kan alltid 
specificeras i förväg. Ett visst steg i kedjan av instruktioner beror inte på någon oförutsedd händelse tidigare i sekvensen. I denna definition ingår inte bara beräkningar utan även alla förutbestämda procedurer som kan krävas för att kunna dra en slutsats. Detta innebär att algoritmen hanterar konceptuella svårigheter i en uppgiftslösning (Lithner, 2008). I tabellen 1 nedan presenteras de centrala delarna av kategoriseringen av resonemang utifrån Lithners (2008) ramverk.

Tabell 1. Sammanfattning av olika typer av resonemang enligt Lithners (2008) ramverk.

\begin{tabular}{|c|c|c|c|c|c|c|}
\hline \multirow{2}{*}{$\begin{array}{c}\text { Kreativt matematiskt } \\
\text { resonemang }\end{array}$} & \multicolumn{4}{|c|}{ Imitativt resonemang } \\
\hline \multirow{2}{*}{ Globalt } & Lokalt & $\begin{array}{c}\text { Bekant } \\
\text { Algoritm }\end{array}$ & Kompisvägledning & Lärarvägledning & Textvägledning & $\begin{array}{c}\text { Memorerat } \\
\text { resonemang }\end{array}$ \\
\cline { 3 - 6 } & &
\end{tabular}

Om inte ett resonemang i sin helhet kan tas ur minnet, kan det ändå imiteras. Ett sätt kan vara att utifrån ett urval av algoritmer välja den man tror passar bäst för situationen, baserat på ytlig karakteristik eller ledtrådar i uppgiften. Ett annat sätt kan vara att få vägledning av en kompis, en lärare eller en lärobok eller annan textkälla. I dessa fall utgör grunden för strategivalet att algoritmen finns tillgänglig. Och implementeringen består således av att imitera någon av dessa källor. Enligt ramverket är de olika typerna av resonemang (se tabell 1) disjunkta kategorier. I verkligheten kan elever snarare visa upp typer av resonemang längs ett kontinuum, från att vara helt baserade på det som definierar ett kreativt resonemang till att vara helt imitativt.

Ramverket har visat sig användbart vid analys av såväl läromedel och prov som lärares arbete och elever i olika sammanhang (Bergqvist \& Lithner, 2012; Lithner, 2004; Palm, Boesen \& Lithner, 2011; Sumpter, 2013). Det jag använt ramverket till i de tre studierna i denna avhandling är att undersöka läromedel ämnade för gymnasiet och jämföra resultaten med läromedel från elva andra länder, att analysera svenska elevers resonemang då de arbetar med läroboksuppgifter, samt att se hur elevers resonemang kan kopplas till elevers uppfattningar om matematik och matematiska resonemang då de arbetar med uppgifter som kräver ett kreativt matematiskt resonemang.

Ramverket förtydligar att en elevs tankebanor styrs och begränsas av elevens förståelse och formas i en sociokulturell miljö, som beskrivs i figur 3. I miljön inkluderas allt som berör eleven eller som berörs av eleven, i en lärsituation (Brousseau, 1997). Huvudsakligen behandlas här distinktionen och relationen mellan utantillinlärning och en djupare förståelse.

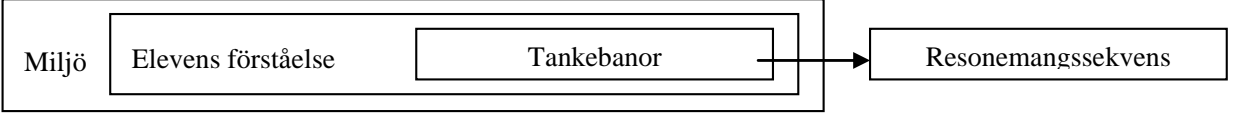

Figur 3. Resonemangets ursprung. (Fritt efter Lithner, 2008). 
Ett matematiskt resonemang ska alltså ses i ljuset av en speciell miljö, där elever och även lärare anpassar sig efter de förutsättningar som miljön ger (Brousseau, 1997). Denna lärmiljö utvecklas som ett slags didaktiskt kontrakt som fungerar som en implicit överenskommelse mellan lärare och elever i ett klassrum (Brousseau, 1997). I det följande avsnittet önskar jag titta närmare på lärmiljön med avseende på skolmatematiken.

\subsection{Kunskap som en individuell konstruktion $i$ ett socialt samspel}

Cobb (1994) jämför det konstruktivistiska och det sociokulturella perspektivet på lärande. Såväl det konstruktivistiska som det sociokulturella perspektivet ser aktiviteter som en språngbräda för utveckling (Cobb, 1994). Då den sociokulturella teorin betraktar aktiviteter som något som sker i en gemenskap med andra individer, anser däremot konstruktivister att en aktivitet är något som en individ genomför för sig själv men i en kontext. Skillnaden mellan de två perspektiven utvecklas av Cobb (1994) genom en diskussion om synen på kunskap. Konstruktivismen ser kunskap som en konceptuell process i individen och en strävan att skapa struktur för nya intryck. Med andra ord är lärande utifrån denna synvinkel högst personligt och baserat på den kontext som tolkas specifikt för varje individ. För den sociokulturella inriktningen har omgivningen en större betyder för kunskap och blir en beskrivning av hur en individ förhåller sig till och förstår nya situationer. Kunskap ses då som något som skapas $\mathrm{i}$ ett socialt samspel och som sedan utifrån miljön befästs $\mathrm{i}$ individens medvetande. För en djupare diskussion av de två perspektiven på lärande hänvisas till någon av förespråkarna för respektive inriktning. Den konstruktivistiska inriktningen förespråkas av bland annat Piaget och von Glasersfeld, medan förespråkare för den sociokulturella synen på lärande till exempel är Vygotsky och Leont'ev.

Cobb (1994) säger att lärande är en individuell konstruktion likväl som en process som pågår i samarbete med den omkringliggande miljön. Med andra ord är den miljö som till viss del kan formas av utbildningssystemet väsentlig för vad elever kan lära sig i skolan. Genom att elever till exempel jobbar i par eller grupp får de möjlighet att reflektera över andras förståelse för det matematiska innehållet (Webb \& Mastergeorge, 2003). En elevs kunskap Detta är en syn som jag i fortsättningen av denna text kommer att förhålla mig till. Det nät av kunskap som skapas är unikt för varje individ, men den kunskap som införlivas i nätet får sin mening med hjälp av det sociala sammanhanget. Förståelsen för en ny information byggs upp utifrån en gemensam överenskommelse i en specifik kontext.

\subsection{Sociomatematiska normer som en grund för möjligheterna till lärande}

Den didaktiska triangeln där läraren, eleverna och ämnesinnehållet utgör de tre hörnen är en vedertagen modell av undervisningssituationen. Det samband som skapas mellan de tre hörnen i triangeln ramar in och skapar de möjligheter till lärande som erbjuds i undervisningen (se figur 4). I resten av detta avsnitt önskar jag beskriva under vilka premisser 
dessa möjligheter till lärande kan förverkligas och existera, utifrån den miljö som gemensamt skapas i samspelet mellan lärare, elever och matematiken.

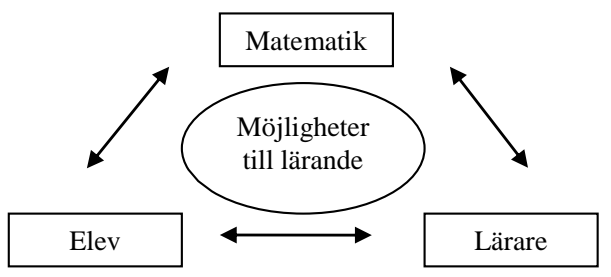

Figur 4. Den didaktiska triangeln som ramar in möjligheterna till lärande.

Ett av syftena med en modell är att förenkla och framför allt förtydliga verkligheten. Huruvida förenklingen är alltför grov har med inramningen och användningsområdet att göra.

Inom ramen för den didaktiska triangeln förhandlas ett didaktiskt kontrakt fram (Brousseau, 1997). Läraren, eleverna och ämnets karaktär är grunden för det kontrakt som kontinuerligt och dynamiskt vidareutvecklas. Cobb, Wood och Yackel (1993) beskriver att den unika kulturen som finns i varje enskilt klassrum är en produkt av vad lärare och elever för med sig avseende kunskap och värderingar, och hur dessa påverkar och påverkas av det sociala samspelet i klassrummet. Kontraktet är en slags implicit överenskommelse kring en mängd, regler eller normer som påverkar och i vissa fall styr interaktionen mellan lärare och elever (Schoenfeld, 2012). De möjligheter att lära som erbjuds i ett klassrum utvecklas inom ramarna för denna överenskommelse. Vissa av dessa regler är mer generella och rör klassrumsinteraktion i allmänhet. Några av reglerna är däremot unika för matematikämnet, sociomatematiska normer, och skapar en normativ bild av ämnet (Yackel \& Cobb, 1996). Att elever förväntas redovisa och förklara sina tankar är exempelvis en social norm, medan vad som betraktas som en acceptabel matematisk förklaring är en sociomatematisk norm (Yackel \& Cobb, 1996). En godtagbar förklaring normaliseras av flera faktorer så som elevernas förståelse för matematiken, lärarens förståelse för elevernas utveckling (Yackel \& Rasmussen, 2002). Överenskommelsen om en förklarings giltighet växer fram i samspelet mellan lärare och elever (Yackel \& Rasmussen, 2002). Cobb et al., (1993) betonar i detta sammanhang vikten av att i klassrummet samtala om såväl matematik som om själva samtalet om matematik. Denna metanivå av samtalet kan påverka hur normerna ser ut. De presenterar ett exempel på ett sådant samtal, med ett tidigt möte mellan en lärare och hans nya elever. 
Eleverna i klassrummet har en stund arbetat enskilt med ett problem, och läraren frågar efter Jacks lösning till problemet. Jack i sin tur förutsätter, utifrån hans tidigare erfarenheter av matematik i skolan, att läraren efterfrågar ett svar och avger detta. Jack hade i detta skede också förväntat sig att få svaret utvärderat. Läraren väljer dock att förtydliga frågan och undrar hur Jack kommit fram till sitt svar. Detta är en indikation till eleven och även resten av klassen om vad läraren anser är ett passande sätt att samtala kring matematik. Jack beskriver hur han löst uppgiften, men inser i samband med detta att han tidigare angivit ett felaktigt svar. I detta tar läraren fasta på att det är tillåtet att göra misstag och att ansträngningen med att tydliggöra sin lösning och att fortsätta att sträva efter korrekthet är väsentlig.

Snarare än ett samtal som strikt håller sig till matematik lutar sig läraren även mot en diskussion kring det matematiska samtalet, en slags metadiskussion. I exemplet visar sig en konflikt i den mån att eleven, Jack och läraren initialt har olika syn på den sociomatematiska normen. Läraren använder i undervisningen den inbyggda auktoritet han har genom sin yrkesroll, till att utveckla den kultur han önskar finns i klassrummet (Cobb et al., 1993). Överenskommelsen blir en jämkning av den syn på matematiken och matematikämnet och dess undervisning som läraren och som eleverna har. Triangeln i figur 4 existerar dessutom i ett vidare didaktiskt system där påverkansfaktorer nära eller längre ifrån klassrummet finns representerade. I det följande ämnar jag därför att bygga på modellen med vidare teorier och fylla den med ytterligare innehåll.

I förhandlingarna kring de sociomatematiska normerna såväl som andra klassrumsnormer inkluderas lärarens uppfattning om vad som bör inbegripas i undervisningen. Denna uppfattning påverkas av en mängd olika faktorer såsom den avsedda läroplanen i form av styrdokument på systemnivå, ämnesdiskussioner på skolan, nationella prov, läromedel, traditioner och influenser från andra miljöer. Även eleverna kliver in i klassrummet med en uppfattning om vad som ska finnas med i ett kontrakt avseende normer, och mer specifikt de sociomatematiska normerna. Det normativa bestäms alltså, bland annat av de uppfattningar som klassrummets deltagare bär med sig (Yackel \& Rasmussen, 2002). När så en norm byggs upp och en oskriven överenskommelse sluts mellan lärare och elever kring ett ämne och dess innehåll, är det inte ett enkelt förhållande mellan lärare och elev, utan snarare ett förhållande där såväl lärare som elev finns i en unik miljö som ligger till grund för det dynamiska och intrikata samspelet. Varje matematikklassrum med sina elever och sin lärare blir en unik miljö som under loppet av kursens gång utvecklar gemensamma sociomatematiska normer, som en delmängd av större mer allmänna undervisningsnormer. I följande exempel åskådliggörs några av de faktorer som indirekt kan påverka de sociomatematiska normerna $\mathrm{i}$ ett klassrum. 
I augusti kliver en lärare in i ett klassrum på gymnasiet och träffar för första gången sina 25 nya elever. Med sig har läraren många års erfarenheter som matematiklärare och även erfarenheter av hur det är att själv vara elev. Läraren har en lärarutbildning som också till viss del format honom. Efter tiden på lärarhögskolan har han dessutom influerats av såväl kollegor som läroböckernas utformning och de nationella proven. Under årens lopp har också de klasser han undervisat satt sina spår i hans syn på skolmatematiken. Eleverna har även de sina unika erfarenheter med sig in i klassrummet, och har förväntningar på vad undervisningen under året ska bjuda på. De erfarenheter som läraren och eleverna tar med sig till klassrummet är inte desamma som samma individer tar med sig till låt oss säga samhällskunskapslektionen, utan är ämnesspecifika och beror på ämnets karaktär och mer specifika erfarenheter i relation till just matematik.

Läraren börjar snart presentera kursen med hjälp av ämnesplanen och den tilltänkta läroboken. Han initierar också förhandlingen kring hur de sociomatematiska normerna ska se ut. Genom sättet som läraren betonar olika aspekter av kursinnehåll, kunskapskrav och bokens upplägg visar han implicit vad han värderar som viktigt. Under nästa lektion inleds arbetet med det matematiska innehållet i kursen. Läraren håller en genomgång vid tavlan men engagerar samtidigt eleverna till en aktiv dialog. Det inledande kapitlet i boken handlar om algebra och det första som presenteras är hur man tecknar och tolkar algebraiska uttryck. Läraren går igenom ett antal exempel på uppgifter eleverna senare under lektionen kommer att stöta på då de jobbar med lärobokens uppgifter. Läraren, tillsammans med läroboken skapar här en i det närmast gemensam röst som beskriver en syn på matematikundervisningen. I elevgruppen sitter ett flertal elever som är vana med arbetssättet som går ut på en lärargenomgång med lösta exempel för att sedan få möjligheten att jobba med liknande uppgifter på egen hand. Dessa elever och läraren torde i detta avseende vara överens om hur den sociomatematiska normen borde se ut. De svar som eleverna får på uppgifterna jämförs med facit för en snabb återkoppling, där just svaret har stor betydelse och där antalet avklarade uppgifter blir till ett mått på framsteg. Dock finns det i gruppen även ett par elever som önskar diskutera begreppen och i vissa fall även utveckla resonemangen kring uttryck till att även innefatta formler och kanske även ekvationer. Frågor som "vad är det för nytta med det här" formuleras och i deras strävan att försöka sätta in det matematiska materialet $\mathrm{i}$ ett större sammanhang visar de möjligen en något annan syn på matematikundervisningen.

För att undervisningen ska gå framåt för hela gruppen känner sig läraren pressad att bedriva en undervisning i helklass och således måste han också inleda en förhandling med klassen som helhet kring hur undervisningen ska bedrivas och vad det slutgiltiga målet bör vara. Då lärarens tid är begränsad finner han det rationellt att använda läroboken i största möjliga utsträckning. Läroboken ger också undervisningen en viss ytterligare auktoritet då inte alla elever i gruppen har samma uppfattning om vad undervisningen bör syfta till. Fortfarande måste dock alla elevers olika syn beaktas då en gemensam norm för det matematiska klassrummet ska skapas. 
Frågan om vilken typ av kunskap som premieras kommer upp då klassen jobbar med ekvationer och några elever har svårt att följa den av läraren presenterade algoritmen för ekvationslösning som innebär att termer "flyttas" mellan de två sidorna av likheten och "byter tecken", och istället prövar sig fram eller i vissa fall jobbar med en alternativ algoritm som dock är svårare att redovisa skriftligt. Läraren diskuterar med eleverna de sju förmågor som eleverna enligt kunskapskraven behöver visa prov på. Åsikterna går isär i och med att det finns flera uppfattningar i klassrummet om vad som är att betrakta som matematik. Läraren påverkas således av såväl läroboken som av kunskapskraven som ställs på eleverna i styrdokumenten.

Den uppfattning kring matematik som läraren sedan gentemot eleverna presenterar är det som skapar utgångspunkten i den implicita förhandlingen kring gemensamma sociomatematiska normer. Rollen som lärare medför en auktoritet som innebär att eleverna särskilt beaktar vad läraren i klassrummet förmedlar med avseende på synen på matematik. Några av eleverna har djupt rotade uppfattningar om vad det borde innebära att kunna matematik som antingen harmonierar med lärarens eller som i viss utsträckning går emot lärarens uppfattning. Dessa uppfattningar kan inte slipas bort direkt, utan utvecklas med tiden och i ett socialt samspel kring de sociomatematiska normerna som förhandlas fram bit för bit. De sociomatematiska normerna växer dynamiskt fram under kursens gång. Läraren och klassen tittar gemensamt på ett äldre nationellt prov för att se vad som krävs för att få ett $\mathrm{E}$ i betyg. Provets utformning kommer även det, i stor utsträckning att påverka elevernas syn på matematik, och därmed också dynamiken i hur de sociomatematiska normerna formuleras.

I exemplet framgår att elevers och lärares agerande visar på deras syn på matematik och påverkar den dynamik som råder i klassrummet avseende de sociomatematiska normerna. Rezat och Strässer (2012) betonar att den didaktiska triangeln finns i ett socialt sammanhang där ett flertal faktorer påverkar en eller flera av noderna i triangeln. Till exempel influeras sannolikt eleverna av vänner och familj i sin syn på ett didaktiskt kontrakt. Även skolan som institution, såväl på lokal nivå som på nationell nivå, påverkar lärare och elever i samspelet i den didaktiska triangeln. På lokal nivå kan de rutiner som finns i ett lärarkollegium influera den enskilde läraren genom samtalen som förs kring kunskapsbegreppet eller utformningen av gemensamma prov. På nationell nivå påverkar styrdokumenten vad som sker i klassrummen. Även faktorer som nationella prov och den bild media förmedlar kring matematikundervisningen kan påverka hur sociomatematiska normer förhandlas fram i klassrummen. Påverkansfaktorer kan således finnas i nära anslutning till klassrummet såväl som längre bort från skolans verklighet. Greer, Verschaffel och de Corte (2002) presenterar en modell där faktorer på olika nivåer påverkar elevers och lärares uppfattningar om matematik. I figur 5 nedan har jag valt att inkludera den didaktiska triangeln i modellen för att ytterligare poängtera att samspelet i klassrummet påverkas av underliggande faktorer. I modellen tydliggörs varifrån influenserna kommer, då sociomatematiska normer förhandlas fram i klassrummet. 


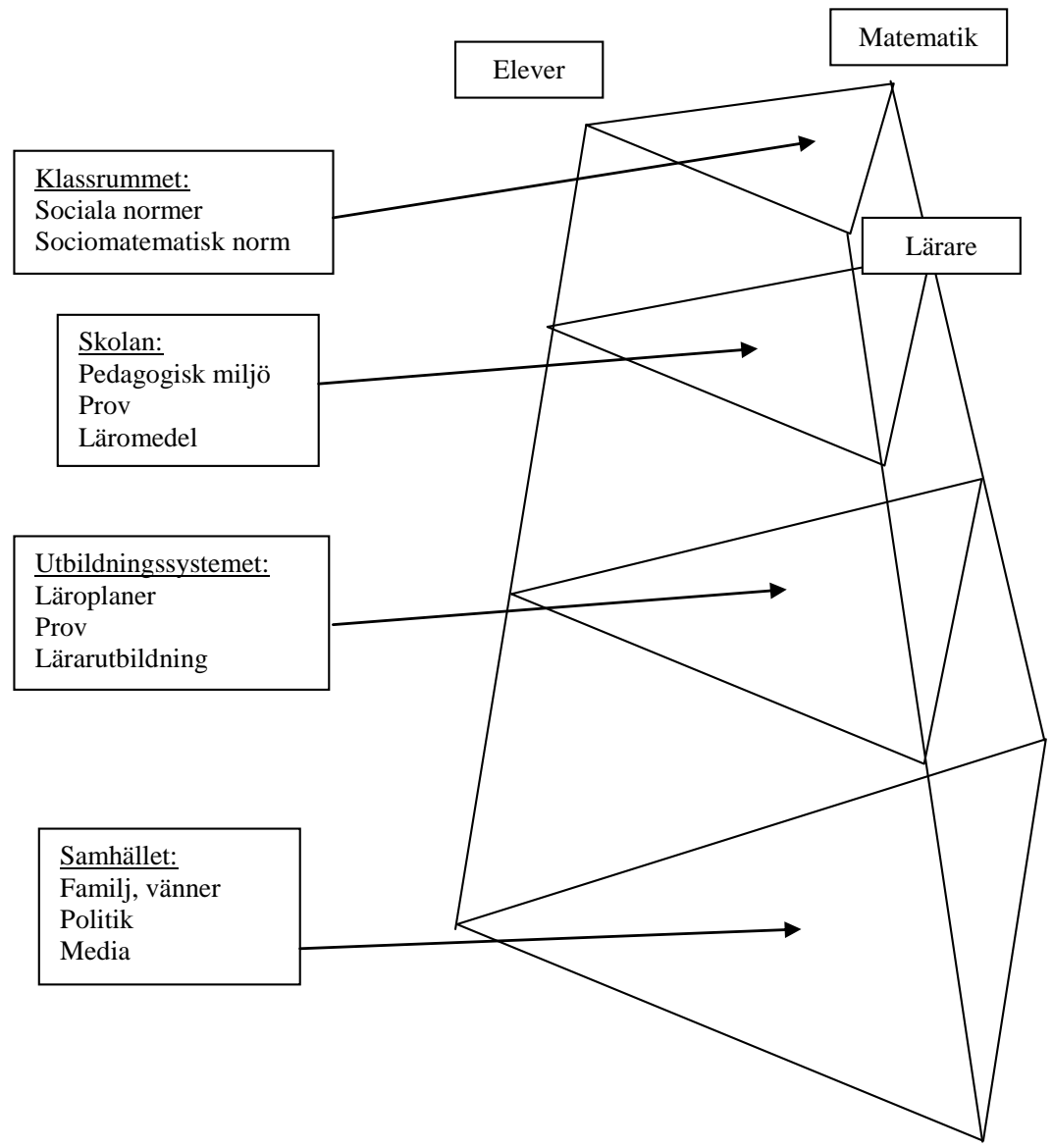

Figur 5. Faktorer som påverkar socio- och sociomatematiska normer.

(Fritt efter Greer et al., 2002).

Elevers möjligheter till lärande påverkas av vilka sociomatematiska normer som råder i klassrummet (Yackel \& Cobb, 1996). I modellen synliggörs det att sociomatematiska normer indirekt påverkas av faktorer såsom den allmänna uppfattningen av matematik, vänner och familj samt olika institutioner såsom den lokala skolan eller högre utbildningsinstanser. Utifrån modellen som den presenterats, med en didaktisk triangel och undre lager av påverkansfaktorer kan en diskussion kring vilka möjligheter till lärande som erbjuds eleverna utvecklas. Den påverkan som de undre lagren till den didaktiska triangeln innebär kan både möjliggöra och begränsa lärandet (Hiebert \& Carpenter, 1992). 


\subsection{Elevers uppfattningar om matematik}

Vad som blir normativt i klassrummet påverkas av såväl kognitiva som icke-kognitiva, mer känslomässiga förmågor och värderingar som alla de i klassrummet aktiva för med sig. Vad en elev lär sig beror på såväl rent kognitiva faktorer som på elevernas bidrag till sociala normer, inklusive de sociomatematiska normerna i form av icke-kognitiva faktorer (Op't Eynde, de Corte \& Verschaffel, 2002).

De kognitiva och känslomässiga faktorerna som en individ för med sig in till det sociala samspelet i klassrummet kan klassificeras utifrån bland annat deras stabilitet över tid (McLeod, 1992). Exempelvis är känslor mer flyktiga och kommer och går relativt snabbt jämfört med till exempel attityder. Ytterligare mer stabila är uppfattningar som influeras i en högre utsträckning av det kognitiva. Uppfattningar betraktas som mer stabila än känslor och attityder och tar längre tid på sig att slå rot i en individ och är även svårare att förändra än känslor. I den engelskspråkiga forskningslitteraturen används affect som en sammanfattande term för de faktorer som är mindre kognitivt betingade än kunskap. Ett rakt motsvarande ord på svenska är svårt att finna. Affekt får en delvis annan, mer känslomässigt betonad innebörd i det svenska språket. Den del av begreppet affect som vi valt att beforska i studie 3, väljer jag här att benämna uppfattningar, vilket ska tolkas som likstämmigt med engelskans beliefs.

Då förhandlingarna kring en sociomatematisk norm pågår är enskilda elevers uppfattningar ett viktigt förhandlingsmaterial. Så att påverka elevers uppfattningar innebär att påverka deras syn på de sociomatematiska normerna, och att också fortsätta att förhandla fram normer.

De tolkningar av de rådande sociomatematiska normerna som elever och lärare gör påverkar de uppfattningar de har om matematikämnet (Greer et al., 2002). Samtidigt som elevernas och lärarnas uppfattningar påverkas av de sociomatematiska normerna påverkas normerna av dessa uppfattningar i ett dynamiskt samspel. Ett unikt kommunikationssystem där elever och lärare interagerar utifrån sina uppfattningar inom ramen för den didaktiska triangeln bygger upp normer. Skapandet, eller förändringen av uppfattningar går med andra ord hand i hand med utvecklingen av en klassrumsnorm (Yackel \& Rasmussen, 2002). Uppfattningar kan således betraktas som individens förståelse av de normativa kraven som ställs i undervisningssituationen (Yackel \& Rasmussen, 2002). Lärare och elever möts i en vidare kontext där deras uppfattningar påverkas både av de gemensamt framförhandlade sociomatematiska normerna och av andra normer som aktörerna är en del av i skolan såväl som utanför densamma (Greer et al., 2002).

Om normen betraktas som något som förhandlas fram i ett socialt sammanhang kan den enskilde elevens (eller lärarens) uppfattningar om matematik och syn på den sociomatematiska normen sägas vara den psykologiska dimensionen av den gemensamma normen (Yackel \& Rasmussen, 2002). Uppfattningarna kommer till uttryck och utvecklas genom att de införlivas i en klassrumsnorm (Op’t Eynde et al., 2002). Sambandet mellan 
normer och individers uppfattningar innebär att en diskussion om uppfattningar är tätt relaterad till en diskussion om normer (Yackel \& Rasmussen, 2002). I modellen med ett didaktiskt torn, som tidigare presenterats kan det vertikala flödet från underliggande plan representera influenser på elevers (och lärares) uppfattningar. Noderna i det över planet, den didaktiska triangeln utgör då representanter för aktörernas uppfattningar, vilka i sin tur samspelar för att bygga upp och påverkas av sociomatematiska normer.

Elevers uppfattningar om matematik har visats sig i hög utsträckning påverka sättet de angriper matematiska problem på (Schoenfeld, 1992), och således också skapat förutsättningar för olika typer av lärande. Sambandet mellan elevers uppfattningar, och inte minst utvecklingen av en konceptuell kunskap bör synliggöras mer (McLeod, 1992). Tidigare forskning har visat att de uppfattningar som elever har om matematik är kontextuellt betingade (Francisco, 2013). I en svensk gymnasieskolekontext har Sumpter (2013) undersökt elevers uppfattningar om matematik och matematiska resonemang, då de jobbar med matematiska uppgifter av standardkaraktär. Sumpter identifierade tre huvudgrupper av uppfattningar, nämligen förväntningar, motivation och säkerhet. Elever har visat förväntningar på såväl sig själva som på matematiken. Motivationen hos en elev kan komma antingen inifrån eller utifrån. En elev kan uppvisa säkerhet eller osäkerhet. Utifrån Sumpters (2013) resultat har analysen i studie 3 bedrivits deduktivt i den meningen att vi utgick från tre fördefinierade kategorier för att undersöka om uppfattningarna är desamma om eleverna erbjuds arbeta med icke-rutinuppgifter som kräver kreativa matematiska resonemang för att skapa en korrekt lösning.

\subsection{Lärobokens betydelse}

Enligt Valverde, Bianchi, Wolfe, Schmidt och Houang (2002) bör en läromedelsanalys ses i ljuset av hur den används. Läroboken är en artefakt som används i ett sampel mellan lärare och elever. Såväl internationellt som i den svenska kontexten finns tydliga indikationer på lärobokens betydelse för hur undervisningen i matematik ser ut. Till exempel redovisas i TIMSS-studien från 2011 (Mullis, Martin, Foy \& Arora, 2012) hur läromedel används i årskurs 8 i några av de i studie 1 inkluderade länderna. Över hälften av eleverna i såväl Australien, Finland, Singapore, Sverige, Sydafrika (åk 9), som 2 av 3 provinser i Kanada undervisas i miljöer där läroboken utgör basen i undervisningen. I TIMSS-undersökningen från 2007 (Mullis et al., 2008) redovisades även detta resultat för Skottland. I USA är siffran $48 \%$, och i Sverige är siffran så hög som $97 \%$. Färre än $10 \%$ av eleverna i de angivna länderna undervisas helt utan lärobok. Skolverket (2003) uppmärksammar också att svensk matematikutbildning till stor del influeras av lärobokens utformning. Istället för att läroplaner och kursplaner är de bärande dokumenten i en lärares arbete bygger en stor del av planeringen av undervisningen på just läroboken, som fungerar som en guide till ämnesplanen. Jablonka och Johansson (2010) beskriver i en svensk kontext ett förhållande mellan läroboken och läraren där bokens giltighet godkänns av läraren samtidigt som boken stöttar läraren i uppbyggnaden av undervisningen. Schmidt et al. (2001) har visat att den utbredning ett 
specifikt matematiskt innehåll får i en bok också styr hur mycket undervisningstid en lärare planerar för detta innehåll. Läroboken förmedlar dock inte bara vilket innehåll som ska presenteras och dess omfattning, utan även sättet på vilket det kan hanteras av lärare i undervisningen (Valverde et al., 2002).

Eleverna påverkas av läroboken indirekt, via lärare och genom deras direkta användning av boken (Rezat, 2012). När eleverna skapar sin bild av vad matematik är, är läroboken en influerande faktor (Valverde et al., 2002). Rezat och Strässer (2012) bedömer att undervisningsverktyg såsom läroboken spelar en så central roll i det sociala samspelet i klassrummet att den didaktiska triangeln bör kompletteras med en fjärde nod för att skapa en didaktisk tetraeder. En lärobok kritiseras dessutom sällan av dess användare (Jablonka \& Johansson, 2010), vilket ytterligare stärker banden till lärare och elever i en didaktisk tetraeder. Läroboken är betydelsefull för vilka sociomatematiska normer som gäller i klassrummet. Ett läromedels möjlighet att omforma en didaktisk situation berättigar dess position i förhållande till den didaktiska triangeln (Rezat \& Strässer, 2012). Läroboken visar ett innehåll som filtrerats av författarna och skapar en slags metakunskap som är viktig att beakta då lärande diskuteras.

Aktiviteterna som genomförs i klassrummet visar vad som är legitimt och vad som är att betrakta som matematisk kunskap (Lampert, 1990). Detta i sin tur påverkar hur den sociomatematiska normen växer fram. Till exempel blir urvalet av uppgifter vägledande då sociomatematiska normer (Yackel och Cobb, 1996) ska förhandlas fram i klassrummet. Detta urval kan visa på synen på hur kunskap skapas. Uppgifters betydelse då sociomatematiska normer skapas poängteras även av Doyle (1983) som beskriver det som att uppgifter påverkar eleverna genom att fokusera deras uppmärksamhet på en speciell aspekt av innehållet och genom att förtydliga hur informationen bör hanteras. Stein och Lane (1996) understryker detta och poängterar att den kumulativa effekten av en undervisning baserad på en viss typ av uppgifter påverkar möjligheterna till lärande som erbjuds och den bild av matematiken som visas upp. Schmidt (2012) beskriver läroboken som en mall för skeendet i klassrummet, och ser tydligt kopplingen mellan läroboken, undervisningen och lärandet. Och trots att ett läromedel kan användas på många olika sätt kan det fungera som indikator på elevernas möjligheter till lärande (Schmidt, 2012). Som ett exempel på detta kan jämföras två av de läromedel som ingått i studie 2 (Sanaghan et al., 2007; Wai Keung, 2013). 
I Sanaghans bok, under rubriken "Solving equations" återfinns 9 lösta exempel av typen; "solve the equation $3 p+7=16$ ", där lösningen presenteras genom att först 7 subtraheras från båda led och sedan en division med 3 utförs. Inget vidare resonemang kring metodens giltighet förs. Den algebraiska komplexiteten stiger ju längre fram i avsnittet man kommer, och ett av de senare exemplen som presenteras av boken är $\frac{x}{2}+\frac{3 x}{4}=\frac{x+2}{3}$. Lösningen visar att det krävs att termerna multipliceras med 12, som är den minsta gemensamma nämnaren. Efter det förkortas respektive term så att ekvationen får följande utseende: $6 x+9 x=$ $4(x+2)$, vilket förenklas och löses steg för steg enligt samma princip som i tidigare exempel. Avsnittet erbjuder eleverna 89 uppgifter av liknande karaktär att lösa och jämföra med ett svar i facit.

I läroboken av Wai Keung, under rubriken "Simple linear equaitons in one variable" ägnas första sidan åt en diskussion kring den utsaga som en ekvation innebär och vad likhetstecknet betyder. Där behandlas dessutom begreppen lösning, rot utifrån en ekvations giltighet, och vad det innebär att lösa en ekvation. Boken använder termer som "balans" och höger och vänster led för att förklara en ekvations uppbyggnad. Begreppen linjär ekvation och ekvivalenta ekvationer presenteras också på sidan. På nästföljande sida återfinns en aktivitetsuppgift kopplat till en mjukvara som följer med boken. Uppgiften består i att bibehålla balansen på en balansvåg där det i respektive vågskål återfinns ett antal marker med numeriskt värde samt en eller flera x-marker. Samtidigt som balansen ska bestå, ska eleverna ta reda på vad som döljer sig bakom marken märkt med $\mathrm{x}$ som återfinns $\mathrm{i}$ den ena vågskålen. För att göra detta behöver eleverna ta bort marker så att en x-marker till sist ligger kvar själv i den ena vågskålen och kan jämföras med en mark med numeriskt värden $\mathrm{i}$ den andra. Innan ett antal lösta exempel presenteras ställs också frågan om $x=-5$ innebär detsamma som $-5=x$ samt om $2 x=x+7$ är detsamma som att säga att $x+7=2 x$. Sex lösta exempel följer sedan och byggs upp på ett sätt liknande det i Sanaghans bok. Eleverna har sedan 22 uppgifter att jobba med på två olika svårighetsnivåer, och sedan sju uppgifter på den högsta svårighetsnivån där ekvationslösning tillämpas på verkliga kontexter och i vissa fall behöver även eleverna själva ställa upp ekvationerna utifrån given information.

Då dessa bägge läromedel används förmedlar de också olika budskap avseende vad som kan betraktas som värdefull matematik. Den presentation som böckerna ger av begreppet ekvation och hur de kopplar det till andra ingående och nära relaterade begrepp skiljer sig markant. Genom att jämföra bokens genomgång med de uppgifter eleverna sedan förväntas jobba med kan de krav som ställs på eleverna också analyseras. Bilden som läroboken ger, och inte minst de uppgifter som eleverna genom läroboken får tillgång till, blir således en högst bidragande faktor till hur de sociomatematiska normerna kommer att se ut. Hiebert och Wearne (1993) har visat att uppgifter påverkar lärandet indirekt genom elevernas syn på matematiken och sättet som de angriper uppgifterna på, vilket i sin tur påverkas av undervisningen och de uppgifter som eleverna möter. 
Många läromedel betecknar sina uppgifter utifrån olika kriterier. För att elevernas möjligheter till lärande ytterligare ska nyanseras är det rimligt att också beakta på vilket sätt boken presenterar uppgifterna. Tillsammans med en analys av elevers arbete med läroboken kan denna data ytterligare bidra värdefullt till diskussionen. I arbetet med urval av läromedel för studien ingående i denna avhandling har jag uppmärksammat att uppgifter grupperas i läromedlen såväl utifrån svårighetsnivå, som en specifik förmåga och det arbetssätt som önskas. Till exempel finns det i flera av de analyserade böckerna grupper av uppgifter av mer undersökande karaktär, under rubriker som "Activity", "Reflection", "Investigate". Under rubriker som "Discuss", "Reflection", "Discuss the concept", "To think about" och "Write in your journal" återfinns uppgifter där ett mer reflekterande förhållningssätt krävs. Även inom den grupp uppgifter som direkt följer på en av bokens genomgångar finns i flera fall en uppdelning. I vissa fall är denna uppdelning uttalat utifrån svårighetsnivå, medan det i andra fall baseras på den förmåga som enligt läroboksförfattarna eleverna ska få möjlighet att öva på. Exempel på rubriker för den grupp som eleverna först stöter på i böckerna är "Basic", "Fluency", "Skill practice" "Practice" och "General". Bland de senare grupperna märks "Understanding", "Reasoning", "Apply", "Extend", "Maths at work", "Brainworks", "Challenge" och "Problem solving".

Ett samband mellan läroboken, sedd som en potentiell bild av den genomförda läroplanen, och den uppnådda läroplanen i form av det eleverna får ut av undervisningen har påvisats $\mathrm{i}$ flera kontexter (Schmidt, 2012). Henningsen och Stein (1997) beskriver det som att en uppgift kan ses ur flera perspektiv, där den initialt betraktas objektivt så som den gestaltats i till exempel en lärobok. Nästa perspektiv i deras modell är sättet på vilket en lärare presenterar uppgiften i klassrummet, följt av hur eleverna arbetar med uppgifter och slutligen vilket utfall i form av lärande det leder till. Samtliga dessa perspektiv bör beaktas för att skapa en så komplett bild som möjligt av hur en lärobok och dess uppgifter påverkar elevernas lärande. I linje med detta föreslår Shield och Dole (2013) att betrakta en läromedelsanalys som en förstanivåanalys som kan ge en av flera bilder av de möjligheter till lärande som erbjuds i skolan. En läromedelsanalys knyts därför med fördel till studier som till exempel visar på hur boken används av lärare och elever.

Speciellt specifika förmågor, så som i detta fall förmågan att resonera matematiskt är möjliga att urskilja och tydliggöra i en läromedelsanalys, för en diskussion kring möjligheterna till lärande enligt Schmidt et al. (2001). Tillsammans med en större förståelse för sättet som elever och lärare använder läroboken kan en tydligare bild av lärobokens betydelse för de sociomatematiska normerna växa fram. 


\section{Metodöverväganden}

I följande avsnitt presenteras något av bakgrunden till de metoder som använts $\mathrm{i}$ de tre studierna. Två separata analysverktyg har använts, ett för analysen av resonemang och ett för analysen av elevers uppfattningar. Analysen av resonemang innefattar såväl uppgifterna i läromedel, som elevresonemang. Samtliga elever samt lärare i de deltagande klassrummen och de elever som ingick i urvalet för studie $3 \mathrm{blev}$ innan datainsamlingen tillfrågade, och accepterade sitt deltagande, genom att skriftligt underteckna ett medgivandeavtal. Lärarna, samt eleverna, som samtliga var över 15 år, såväl som elevernas målsmän informerades om att ljud- och bildupptagning skulle ske, samt att enstaka elevers anteckningar skulle kopieras. Elever och målsmän informerades också om att ingen insamlad data skulle användas annat än i forskningssammanhang. Vidare är i alla sammanhang där eleverna refereras till namnen fingerade. De etiska överväganden som gjorts har skett utifrån Vetenskapsrådets riktlinjer (2011).

Diskussionen kring elevers möjligheter att lära sig resonera matematiskt stärks av de olika metoder som använts i de tre studierna, så som analysen av läromedel, videofilmning såväl i som utanför klassrummet, elevintervjuer och insamling av elevlösningar till uppgifter. Insamlingen av data har dessutom skett i fler än en skola och vid fler än ett tillfälle. I möjligaste mån har också den kontext i vilken datainsamlingen skett beskrivits i respektive studie.

\subsection{Kategorisering av resonemang i läromedelsuppgifter}

Läromedelsanalysen har genomförts som en förstanivåanalys där det som står i läroboken analyseras, snarare än sättet som uppgifterna presenteras i klassrummet. Detta motsvarar det första perspektivet i Henningsen och Steins (1997) modell som diskuterats i bakgrunden. För att analysera vilka möjligheter till resonemang som erbjuds av en lärobok undersöks om en uppgift kan lösas med hjälp av textvägledning från boken, eller om en elev för att lösa uppgiften måste utföra ett kreativt matematiskt resonemang enligt resonemangsramverket som tidigare presenterats (Lithner, 2008). Ramverket har tidigare använts för liknande analyser av provuppgifter och uppgifter i läromedel på universitetsnivå (Boesen, Lithner \& Palm, 2010; Lithner, 2003; Palm et al., 2011). Stein, Remillard och Smith (2007) poängterar att genom att se skillnader mellan olika uppgifter kan också olika möjligheter till lärande urskiljas. För varje uppgift har bokens teorigenomgångar, lösta exempel, fakta och även tidigare uppgifter genomsökts för att finna stöd för en lösningsmetod som kan appliceras på uppgiften eller en del av uppgiften. Om ett sådant stöd finns tidigare i boken, i samma avsnitt som uppgiften, eller med en karaktäristik som liknar den i uppgiften (Palm et al., 2011) och gör det möjligt för eleven att koppla ihop de två, betraktas det också som tillgängligt för eleverna. Detta innebär i sin tur att en elev kan lösa uppgiften i fråga utan att föra ett matematiskt resonemang. För varje uppgift noterades också vilken kategorisering som gjorts av läromedelsförfattarna avseende till exempel svårighetsnivå eller arbetssätt enligt tidigare presentation i bakgrunden. Jag är ödmjuk inför det självklara i att en läromedelsanalys också 
bör ses i ljuset av hur läromedlet används (Rezat \& Strässer, 2012). Läroboken är ett verktyg som används av lärare och elever i ett samspel i klassrummet. I en verklig situation kan en uppgift som en viss elev löser med hjälp av ett imitativt resonemang, kräva ett kreativt resonemang av en annan elev. Detta beror till exempel på de förkunskaper som eleverna har då de läser och tolkar lärobokens presentationer.

En läromedelsanalys kan ses som en av flera bilder av de möjligheter till lärande som erbjuds eleverna. När man betraktar läromedel som en objektiv faktor för de möjligheter till lärande som erbjuds, kan läromedlets potential att vara såväl ett stöds som en begränsning i lärandet analyseras (Herbel-Eisenmann, 2007). Studien kan bidra med en del av underlaget för en diskussion kring vilka möjligheter till lärande som erbjuds. Ett led i detta är att skapa en ökad förståelse för vilka budskap som läromedel i sig bär med sig. För att bättre förstå lärobokens roll i ett didaktiskt system krävs att såväl lärobokens utformning som hur den används av elever och lärare (Herbel-Eisenmann, 2007) undersöks. Att kategorisera läromedelsuppgifter gör det också praktiskt möjligt att jämföra flera olika länder på ett relativt omfattande sätt. I studien ingår en kategorisering av knappt 6000 läroboksuppgifter från 12 olika länder. Trots en avsaknad av, till exempel en diskussion kring hur läromedel används i respektive land, och ett urval av länder, där endast engelsk- och svenskspråkiga läromedel finns representerade, bedöms att generella slutsatser kring läromedelsuppgifters krav kan dras. Urvalet av läromedel baserades på läromedel som var vanligt förekommande i undervisningen i respektive land. Törnroos (2005) har påvisat en korrelation mellan lärobokens utformning och elevers lärande i en finsk kontext, beaktandes specifika matematiska områden och också under en längre tidsperiod än ett läsår. I urvalsprocessen tillfrågades erfarna matematikdidaktiska forskare, lärarutbildare, lärare och skolledare om vilka böcker de i sina respektive länder ansåg vara just mest använda. Dessa fick ingen kostnadsersättning för sitt deltagande i studien. Kontakter i 13 länder användes, och tolv av dessa länder ingår också i studien. Avseende England erhölls inget svar. Urvalet skedde utifrån uppfattningen att samtliga böcker skulle vara möjliga att analysera utan översättningar, med potentiella risker för feltolkningar. Således bestod underlaget av länder där undervisningen på gymnasienivå bedrivs i en större omfattning på antingen engelska eller svenska. På detta sätt var kategoriseringen möjlig att genomföra med en hög reliabilitet, där även initialt, alla uppgifter medkodades av medförfattare till studien. Detta i sin tur stärkte metoden så att en samstämmighet till $98 \%$ nåddes $\mathrm{i}$ kategoriseringen. Till min vetskap har inga matematikläromedelsstudier de senaste 30 åren, förutom de baserade på TIMSS-studierna, inkluderat ett urval av fler än tre länder. Detta i sin tur innebär att urvalskriterierna för studien varit explorativa och baserats på en spridning i termer av geografisk position, vilket lett till att länder i fem världsdelar inkluderats i studien. Vidare skedde ett urval inom respektive bok eller bokserie utifrån det matematiska innehållet. För att möjliggöra en jämförelse av möjligheterna till lärande bör de matematiska områden som behandlas i de olika böckerna vara likvärdigt (Schmidt et al., 2001). Två huvudområden centrala för 
matematikundervisningen på gymnasienivån valdes ut, algebra och geometri. Inom dessa två områden specificerades urvalet ytterligare till "ekvationer och formler" respektive "omkrets, area och volym". Detta urval baserade sig på den indelning av det matematiska innehållet som gjorts i TIMSS ramverk (Mullis et al., 2008). Detta innebar också att läromedlen som slutligen analyserades riktade sig till elever i något skiftande åldrar, mellan 13 och 17 år, men där merparten av böcker var ämnade för elever i åldern 15-16 år och som gick sitt tionde år i skolan. Ramverket möjliggör en analys av ytterligare läromedel för en utvidgning av jämförelsen. Resultaten, tillsammans med resultat kring hur läroboken används och andra klassrumsnära faktorer kan även bidra till en diskussion kring elevers möjligheter att lära sig resonera matematiskt så som önskat.

Urvalet av uppgifter för studien 2 skedde naturligt utifrån vad eleverna jobbade med under just de lektionstillfällena som datainsamlingen ägde rum. Dessa uppgifter kategoriserades sedan i enlighet med metoden som användes för studie 1. Svårighetsnivån hos en uppgift har visat sig påverka elever som antingen kan bli frustrerade eller uttråkade (Kloosterman, 2002). För genomförandet av studie 3 sökte vi aktivt efter uppgifter med en ökande svårighetsnivå, för att eleverna skulle erbjudas en utmaning på lämplig nivå. Uppgifter från tidigare nationella prov, och som bedömdes svara mot innehåll och krav för den aktuella kursen (matematik 1) kategoriserades för ett urval baserat på krav på ett kreativt matematiskt resonemang. Urvalet av uppgifter för studie 3 skedde utifrån en kategorisering med en metod liknande den för studie 1, med den skillnaden att relationen mellan lärobok och elev beaktades ur en något annan synvinkel. Uppgifterna som eleverna i studie 3 löste tillhandahölls på lösblad, skiljt från boken. Detta distanserar alltså uppgifterna från specifika avsnitt i boken. Uppgifterna behandlade dessutom olika matematiska områden, som eleverna inte nödvändigtvis hade arbetat med nyligen. Kriterierna för att urskilja en icke-rutinuppgift har tidigare använts av Boesen et al. (2010) för att kategorisera en prov uppgift som krävandes ett kreativt matematiskt resonemang i relation till den av eleverna använda läroboken. Detta innebar att en lösningsmetod för en uppgift inte skulle förekomma fler än tre gånger i boken.

\subsection{Kategorisering av elevresonemang}

Resonemangsramverket (Lithner, 2008), har tidigare använts i liknande studier i andra kontexter (Boesen et al., 2010; Lithner, 2004; Sumpter, 2013). Då elevers faktiska resonemang analyseras underlättar en uppdelning av arbetsgången i olika moment, vilka tillsammans utgör en resonemangssekvens. Genom denna strukturering kan vi urskilja de argument som eleven använder, explicit eller implicit, under olika delar av sin uppgiftslösning. En uppgiftslösning kan också delas in i fler än en resonemangssekvens 
För att kunna kategorisera olika typer av resonemang särskiljs fyra moment i en resonemangssekvens.

1. Eleven stöter på en (del)uppgift där det inte är uppenbart hur han ska gå vidare

2. Ett val av strategi görs, där "strategi" kan innebära allt från delalgoritmer till mer generella angreppssätt, och "val" betraktas i en vidare mening som exempelvis minnas, återkalla, skapa, upptäcka, gissa osv. Ett strategival kan stöttas av predikativa argument som svarar på frågan varför just denna strategi kommer att lösa uppgiften.

3. Strategin som valts, genomförs. Genomförandet kan slutligen stöttas av verifierande argument som svarar på frågan varför den valda strategin löste uppgiften.

4. En slutsats nås.

I och med att uppgiftslösningen och även resonemanget struktureras på detta sätt möjliggör det att elevers argument identifieras och används för att kategorisera resonemangets karaktär. Metodvalet för den andra studien, då elevers resonemang skulle analyseras var att göra detta $\mathrm{i}$ klassrummet, under lektionstid, för att göra så få förändringar av elevernas naturliga undervisningsmiljö som möjligt. Två elevpar eller grupper valdes ut under lektionstid, efter några minuters arbete med läroboksuppgifter. Urvalet tog hänsyn till graden av matematisk aktivitet och dialog för att öka möjligheten till värdefull data. Inga andra aspekter såsom till exempel genus eller prestationer/betyg vägdes in urvalet, och därför kan inte heller några slutsatser kring dessa aspekter dras. Jämfört med exempelvis så kallade "think aloud protocols", där eleverna ombeds att högt delge sina tankar vid uppgiftslösning, medför den valda metoden även att data kan samlas in under vanliga lektionsförhållanden. Dock innebär det att elever som jobbar enskilt inte finns representerade i data. Schoenfeld (1985) bedömer det ändå som en metod med god giltighet, då eleverna vid pararbete med större sannolikhet visar upp då de inte vet hur de ska komma vidare, och resonerar kring den uppstådda situationen, och även mer tydligt visar på vilka grunder de gjort sina val i uppgiftslösningsprocessen. En nackdel som Schoenfeld (1985) presenterar är att en elev ensidigt kan dominera en grupp eller par. Till viss del går det att komma till rätta med detta då varje enskild elevs resonemang analyseras, snarare än gruppens. Inom paren var det inte sällan uppenbart att typen av resonemang var olika. De enskilda elevernas resonemang var oftast möjliga att urskilja. I några fall saknades erforderlig data för en tillförlitlig kategorisering, medan dialogen i ett fåtal fall medförde att de två elevernas resonemang blev alltför nästlade för att särskiljas och analyseras vidare.

Elevernas uppgiftslösande filmades med ljudupptagning och detta material transkriberades för att tillsammans med elevernas skriftliga lösningar till uppgifterna samt de använda läromedlen utgöra data. Tidigare insamlingar av klassrumsdata med hjälp av videofilmande har betonat fördelar som större detaljrikedom i en analys i och med att situationerna kan betraktas flera gånger och med olika syfte, samt att det möjliggör för fler personer att aktivt delta i analysprocessen (Hiebert et al., 2003). Datainsamlingen skedde i två kommuner, på 
naturvetenskaps-, teknik-, bygg och anläggnings- och handels och administrationsprogrammet, samt det estetiska programmet. I samtliga fall gick eleverna det första året på gymnasiet och läste någon av de två första kurserna i matematik. Två elevpar eller grupper per lektion filmades och i varje klass skedde datainsamling vid 2-3 tillfällen. Detta renderade 26 filmer à 30-45 minuter. För analys valdes i samtliga fall det första lektionstillfället och 5 elevpars och en grupp om 3 elevers uppgiftslösande analyserades. Eleverna från handelsprogrammet analyserades inte på grund av att de inte i erforderlig utsträckning ägnade lektionstiden åt att lösa matematikuppgifter eller löste uppgifter tyst. Innan analysen, kalibrerades för ökad reliabilitet, analysverktyget av samtliga författare. Detta skedde genom enskilda analyser som därefter diskuterades för att nå samstämmighet.

Urvalet av elever för den tredje studien skedde efter en dialog med två undervisande lärare i tre klasser. Elevpar efterfrågades som var vana att arbeta tillsammans och som förväntades precis klara av kursen, som i detta fall var Matematik 1. Inga andra aspekter såsom till exempel genus, närvaro eller tidigare betyg vägdes in urvalet, och därför kan inte heller några slutsatser kring dessa aspekter dras. Totalt fyra stycken elevpar, två från vardera byggprogrammet respektive samhällsprogrammet i två kommuner valdes ut. Eleverna ombads att i par lösa fyra uppgifter i ett avskilt rum med tillgång till såväl lärobok som miniräknare. De slutsatser som således dras av studiens resultat är begränsade till dessa förutsättningar, och hade möjligen sett delvis annorlunda ut om studien till exempel genomförts i ett klassrum. Eleverna ombads att kommunicera muntligt med varandra kring sina tankar och lösningar kring uppgifterna. Inom en veckas tid genomfördes även intervjuer enskilt med samtliga åtta elever, där filmklipp från uppgiftslösningen visades för att återkalla minnet från tidigare, för att ytterligare förstärka analysen. Metoden med filmning av uppgiftslösning och efterföljande intervjuer har använts i tidigare studier (Bergqvist, Lithner \& Sumpter, 2008; Boesen et al, 2010). Såväl elevparens uppgiftslösande som de enskilda intervjuerna filmades med ljudupptagning och detta material transkriberades för att tillsammans med elevernas skriftliga lösningar till uppgifterna utgöra data. Totalt ingick 5 timmar filmat material i data. I den slutliga analysen av data valdes de tre elever ut som bedömdes gett mest data och som också bedömdes visa upp olika typer av uppfattningar och något olika angreppssätt i uppgiftslösningen. I vår process med data har analysarbetet hela tiden gjorts av fler än en av författarna, vilket skapat en större reliabilitet än om en enskild person gjort arbetet.

\subsection{Att studera elevers uppfattningar}

Jag är medveten om att en analys av elevers uppfattningar om matematik och matematiska resonemang innebär att tolkningar görs, vilket också bekräftas av Furinghetti och Morselli (2009). Uppfattningarna i studien har tillskrivits egenskaper i form av namn eller teman. Furinghetti och Morselli är ödmjuka inför att andra tolkningar kan göras, men att en analys ändå kan presentera en, av flera bilder av hur uppfattningarna kan tolkas och relateras till elevers agerande. Snarare än att analysera uppfattningar har vi analyserat indikationer på uppfattningar som finns i data. En indikation på en uppfattning definieras av Sumpter (2013) 
som ett teoretiskt begrepp och del av en modell vars syfte är att beskriva ett specifikt fenomen, i detta fall utsagorna från elever då de löser matematiska uppgifter. För att analysera dessa indikationer har en tematisk analys genomförts. Den tematiska analysen har noggrant inkluderat elevernas utsagor $\mathrm{i}$ form av muntliga uttalanden, gester och även skriftlig kommunikation i form av uppgiftslösningar. Då indikationen inte var tydlig har den utelämnats. Indikationerna på uppfattningar har sedan tolkats i den kontext de har sitt ursprung, och utifrån ett deduktivt tillvägagångssätt relaterats till de tre teman på uppfattningsindikationer, förväntningar, motivation och säkerhet (se bakgrunden) som presenterats av Sumpter (2013). Då relationen mellan elevernas uppfattningar och resonemang skulle studeras skedde insamlingen av data enligt beskrivningen i stycket ovan. Uppfattningsindikationerna har dessutom kopplats till de resonemang som eleverna använt i situationen. I vissa fall bestod denna koppling av en eller flera uppfattningsindikationer och ett byte av resonemang. Analysen har i sin helhet genomförts gemensamt och i samförstånd mellan två av författarna, vilket skapat en ökad reliabilitet. Initialt har även den tredje författaren deltagit $i$ analysen och stärkt stabiliteten av densamma ytterligare. En stärkt reliabilitet avseende analysen av elevernas matematiska resonemang bedöms erhållas i och med att analysverktyget är det samma som i den tidigare genomförda studie 2 .

\section{Om studierna och deras resultat}

De tre studierna som ingår i avhandlingen har alla haft ett gemensamt syfte att studera matematiska resonemang på gymnasiet. Detta sker genom tre olika perspektiv. Ett är en analys av läromedel, ett är en undersökning av vilka typer av matematiska resonemang elever använder i klassrummet, och det tredje perspektivet innebär att elevers resonemang relateras till de uppfattningar om matematiska resonemang och matematik de visar upp. I följande avsnitt presenteras kortfattat de resultat som erhållits i respektive studie, samt något om de slutsatser som dras i relation till dessa resultat.

\subsection{Sammanfattning av studie 1: Reasoning requirements in school mathematics textbooks: an analysis of books from 12 countries.}

Den första studien är en internationell läromedelsanalys där vanligt förekommande läromedel från tolv olika länder analyserats. Läromedel från Australien, Kanada, Finland, Irland, Indien, Nepal, Skottland, Singapore, Sydafrika, Sverige, Tanzania och USA ingår i studien. Uppgifter inom algebra och geometri analyserades med avseende på vilka krav på resonemang som de ställer på eleverna i kontexten av läroboken som en vägledare i uppgiftslösandet. Mer specifikt har uppgifterna i läromedlen jämförts med bokens övriga innehåll i en strävan att bedöma huruvida ett matematiskt resonemang krävs för att lösa uppgiften eller inte. Samtliga böcker är hämtade från motsvarande gymnasieskolan, "upper secondary school" eller "high school", och är ämnade för elever i åldersspannet från 13 till 17 år. Total har knappt 6000 uppgifter kategoriserats, och trots att länderna representerar olika nivåer av resultat i internationella kunskapsjämförelser (Mullis et al., 2012; OECD, 2014), och geografiska 
positioner i fem olika världsdelar, visar resultaten att andelen uppgifter som kräver ett kreativt matematiskt resonemang (lokalt eller globalt) är jämförbart i de olika länderna. Andelen uppgifter som kräver ett globalt kreativt resonemang var i genomsnitt 8 procent för algebraavsnitten och 12 procent för geometriavsnitten. Denna andel är avsevärt mindre i den grupp av uppgifter eleverna först stöter på inom varje nytt avsnitt. Något som blir intressant att beakta i den svenska kontexten där vi även sett att eleverna främst jobbar med dessa första, enklare uppgifter. Detta innebär givetvis också att andelen uppgifter där eleverna får en möjlighet att träna på att resonera matematiskt, snarare än att imitera minskar. Den relativa homogenitet som syns i resultaten av den internationella läromedelsanalysen indikerar att om urvalet är representativt för respektive land så är läroboken inte den enda faktorn som påverkar resultaten i matematik. I ett klassrum där fokus läggs på de traditionella uppgifterna och för en elev som främst jobbar på grundläggande nivå kan i vissa fall möjligheten att träna resonemangsförmågan i det närmaste helt utebli.

5.2 Sammanfattning av studie 2: Students' reasoning in mathematical textbook task-solving. I den andra studien jämförs de resonemang som elever använder då de löser läroboksuppgifter i reella undervisningssituationer med kategoriseringar av vilka krav uppgiften ställer avseende resonemang. Elever videofilmades i sitt uppgiftslösande under lektionstid och deras resonemang analyserades och kategoriserades med hjälp av ramverket för resonemang (Lithner, 2008) som presenterats tidigare. Elever som jobbade i parkonstellationer valdes ut för att på så sätt få tillgång till deras tankeprocess indirekt via de resonemang som verbalt uttrycktes. Undersökningen gjordes i den svenska gymnasieskolan och visar att eleverna till mycket övervägande del jobbar med de enklare uppgifterna i boken och sällan stöter på uppgifter som kräver ett kreativt matematiskt resonemang. Resonemanget som eleverna för överensstämmer också i mycket hög grad med de krav som uppgiften ställer. $80 \%$ av alla analyserade uppgifter löstes framgångsrikt med imitativa resonemang. Vidare visar studien att eleverna ofta vägleder varandra på så sätt att algoritmer presenteras för varandra i syfte att lösa en uppgift snarare än för en djupare matematisk förståelse. I de fall då elever sökte stöd av läraren i sitt uppgiftslösande ledde det till ett imitativt snarare än kreativt resonemang. Då eleverna fick problem med att lösa en uppgift var huvudalternativet för den fortsatta processen nästan uteslutande att fråga en kompis eller lärare om hjälp. Detta innebär i praktiken att en potentiell möjlighet att få träna på ett kreativt resonemang försvinner. Eleverna använde sällan lärobokens presentationer eller lösta exempel som ett stöd i sin uppgiftslösning. Däremot användes facit, som återfinns längst bak i boken snarare än egna argument för en verifikation av en metods giltighet. Utifrån dessa resultat kan slutsatsen dras att även i beaktande hur läroboken används skapas få möjligheter till att lära sig resonera kreativt. Även arbetsmetoderna avseende arbete i par och sättet på vilket lärare vägleder elever i uppgiftslösningen diskuteras. I bägge fall krävs ett strukturerat och organiserat arbetssätt för att förstärka elevernas möjligheter att använda kreativa matematiska resonemang i sin uppgiftslösning. Dessutom skapar sättet som läroboken används av eleverna frågor kring 
bokens utformning. Läromedelsförlagen bör fråga sig om facit snarare än bokens genomgångar ska stå för den främsta vägledningen då eleverna jobbar med bokens uppgifter.

\subsection{Sammanfattning av studie 3: Students' mathematical reasoning and beliefs in non- routine task solving.}

I avhandlingens tredje studie har vi undersökt vilka uppfattningar om matematik några elever har i relation till matematiska resonemang. Elevpar filmades då de arbetade med ickerutinuppgifter, i en avskild miljö. Uppgifterna bedömdes kräva ett kreativt matematiskt resonemang för att lösas. Eleverna ombads att tala högt med varandra kring vad de gjorde och varför. Samtliga elever intervjuades också för en möjlighet till klargöranden av data. Urvalet av elever bestod av elever som förväntades precis klara kursen, då elever som får betyget $\mathrm{F}$ eller E utgör mer än hälften av alla elever som läser denna kurs. Tre elever analyserades djupare, och de använda resonemangen kopplades till indikationer på elevernas uppfattningar om matematik. De tre eleverna visade upp olika relationer mellan deras respektive uppfattningar och de resonemang som de använde. Såväl imitativa som kreativa matematiska resonemang användes. Bilden av de uppfattningar och de resonemang som elever använder har breddats jämfört med tidigare resultat (Sumpter, 2013). Att eleverna jobbade med ickerutinuppgifter synes ha en påverkan på deras resonemang. En av eleverna förstärker bilden av osäkerhet, låg förväntningar på sig själv, en negativ inre motivation och förväntningar på att kunna använda sig av algoritmer för att lösa uppgifterna. Denna elev använder sig också av imitativa resonemang för att lösa uppgifterna med ett svagt resultat. Eleven överger vid flera tillfällen ett korrekt kreativt resonemang. Resultaten visar också att två elever uppvisar delvis annorlunda uppfattningar och även i större utsträckning använder kreativa matematiska resonemang, speciellt då de känner sig ha en komplett lösning inom räckhåll. En av dessa elever genomför korrekta kreativa matematiska resonemang medan den andra inte i något fall lyckas lösa uppgiften korrekt. De uppfattningar som indikerades av dessa två elever var mer blandade än hos den första eleven, då de visade såväl negativ som positiv inre motivation och såväl säkerhet som osäkerhet. Eleverna hade dessutom förväntningar på uppgifternas svårighetsnivå och att lösningen skulle harmoniera med denna nivå. Dessutom indikerades en uppfattning om att lösningsredovisningar enbart syftade till att tillfredsställa läraren och inte som ett verktyg i lösningsprocessen. Vad skillnaderna jämfört med tidigare forskning (Sumpter, 2013) kan bero på diskuteras. En hypotes är att elever med låg procedurell förmåga tvingas försöka lösa uppgifter med kreativa matematiska resonemang, och att urvalet av elever för denna studie till viss del uppfyllde detta kriterium. Situationen, där inget facit eller lärare heller finns till hands kan möjligen hindra eleverna från andra metoder. Anledningen till att eleverna använder kreativa resonemang kan givetvis också bero på att deras undervisning stimulerat till detta. Trots att uppgifterna, som tidigare noterats, verkar påverka elevernas resonemang, används alltså imitativa resonemang trots att något annat krävs, vilket indikerar att det krävs mer än arbete med icke-rutinuppgifter för att stötta eleverna $i$ att skaffa sig en bred matematisk kompetens och i att använda kreativa matematiska resonemang. 


\section{Diskussion}

Ett huvudsyfte med studierna i denna avhandling har varit att skapa en större förståelse för vad som sker i skolan idag med avseende på matematiska resonemang, och hur elevers möjligheter att lära sig resonera matematiskt påverkas av faktorer såsom läromedel och deras egna uppfattningar. Resultaten fungerar som en utgångspunkt för det som diskuteras, med stöd av de i kappan tidigare presenterade teorierna kring möjligheter till lärande, matematisk kunskap, matematiska resonemang, sociomatematiska normer och elevers uppfattningar om matematik och matematiska resonemang. Dessutom knyts diskussionen till andra forskningsresultat. Forskning har tydligt visat på vikten av en syn på matematiken som mer än mekaniskt läroboksräknande. Elever måste få möjligheter att träna på sin förmåga att resonera matematiskt och att lösa matematiska problem (Hiebert, 2003). Bilden av undervisningen som Dewey (1929) målade upp och som presenterades i introduktionen, kan liknas vid dagens situation. Stort fokus vid elevernas matematiska arbete läggs vid att producera svar på uppgifter, snarare än att skaffa sig kunskap. Resultaten från studierna i denna avhandling visar inte på att möjligheterna till lärande, med avseende på matematiska resonemang och en bredare matematisk kompetens erbjuds i skolan idag i en erforderlig omfattning. Två av de frågor jag i den fortsatta texten önskar diskutera är varför det till synes finns en snedvridning $\mathrm{i}$ undervisningen, och också möjliga sätt att påverka undervisningen i en positiv riktning. Brousseau (1997) säger att eleverna, såväl som lärarna måste anpassa sig till en miljö i vilken lärandet sker. Lärare och elever måste tillsammans acceptera de förutsättningar under vilka de jobbar, men kan samtidigt påverka dessa förutsättningar. Hiebert och Wearne (1993) poängterar att två avgörande faktorer för att koppla samman undervisning och inlärning är de rådande klassrumsnormerna och de uppgifter som används i undervisningen. I diskussionen av resultaten har jag valt att speciellt beakta klassrumsarbetet och mer specifikt relationen elever emellan och mellan lärare och elever för att skapa sociomatematiska normer, samt läroböckerna och dess uppgifter som tongivande i skapandet av sociomatematiska normer.

\subsection{Klassrumsarbetet}

Resultaten av studie 2 visar att när elever jobbar med uppgifter i läroboken löser de främst de enklare uppgifterna i boken, som sällan innehåller krav på mer än imitativa resonemang. Eleverna använder inte heller mer än vid enstaka tillfällen kreativa matematiska resonemang. Inte heller i provsituationer använder sig gymnasieelever av kreativa matematiska resonemang i större utsträckning, utan använder sig istället av imitativa resonemang genom att egenskaper i uppgiften kopplas till tidigare inlärda algoritmer (Boesen et al., 2010). Däremot ökar sannolikheten för att eleven använder ett kreativt matematiskt resonemang om en provuppgift tydligt skiljer sig från det eleven tidigare mött i läroboken (Boesen et al., 2010). Elevernas arbetssätt har tidigare beskrivits av Rezat och Strässer (2012) som svarsfokuserat. Elevers målsättning då de arbetar med läroboksuppgifter är att lösa uppgiften snarare än att lära sig matematik. Liknande resultat har även presenterats avseende universitetsstudenter (Lithner, 2003). Sfard och Linchevski (1994) har i sin forskning identifierat elever som söker tryggare metoder baserade på algoritmer, istället för att utifrån 
situationen skapa den mest rationella lösningen. Detta avspeglar sig även i att eleverna i de i avhandlingen ingående studierna använder sig av imitativa resonemang utan framgång snarare än att lita på ett kreativt matematiskt resonemang, även då så bedömts krävas. Enligt Engelbrecht, Bergsten och Kågesten (2009) kan detta bero på att elever är vana med att kunna använda algoritmer och också tror sig ha en förväntan på sig att presentera en algoritmisk lösning, även om denna lösning visar sig mer omständig än en lösning baserad på ett kreativt matematiskt resonemang.

De indikationer på uppfattningar kring matematik som elever visar upp i samband med lösning av uppgifter som kräver ett kreativt resonemang visar på likheter med de uppfattningar som tidigare presenterats i relation till elevers arbete med rutinuppgifter (Sumpter, 2013). Eleverna indikerar förväntningar på såväl ämnet som sin egen förmåga, olika grader av säkerhet och osäkerhet och motivation. Trots olikheter i kontext går en viss likstämmighet att urskilja i resultaten från flera tidigare studier på elevers uppfattningar kring problemlösning. Elever uppvisar en syn på matematiken som algoritmisk med stort fokus på att göra snarare än att förstå och med fokus på resultat snarare än processer och på begränsad reflektion och snabba hanteringar (McLeod, 1992; Schoenfeld, 1992). I studie 3 indikerades en förväntning på uppgifterna att kunna lösas med en välbekant algoritm. Denna uppfattning indikerades i samband med osäkerhet och till viss del en låg förväntning på sin egen förmåga, samt en negativ motivation. Dessa uppfattningar leder också till att sättet som eleverna angriper uppgifter på, påverkas och att möjligheterna till att lära sig, till exempel att resonera på ett kreativt matematiskt sätt inte utnyttjas. Eleverna i studie 3 använde kreativa matematiska resonemang till viss del, men även imitativa resonemang. Fler kreativa matematiska resonemang användes för att slutföra uppgifterna då eleverna kände sig ha en komplett lösning inom räckhåll. En förväntan på uppgifters svårighetsnivå indikerades också, och kan möjligen kopplas till elevernas resonemang på uppgiften. Kloosterman (2002) uttrycker att elever oftast har en tydlig bild av en uppgifts svårighetsnivå och att eleverna angriper uppgiften utifrån denna förväntan. En elev vars förväntan på en uppgift är att den ska vara enkel skulle till exempel, i kombination med en låg förväntan på sig själv kunna anse ett kreativt matematiskt resonemang som alltför komplicerat. Då en elev möter en uppgift som däremot har en förväntan på sig att vara svår, kan frustration skapas hos eleven vilket skulle kunna leda till att en trygghet söks genom användandet av välbekanta algoritmer. Ett liknande, algoritmiskt beteende kan också förstärkas av den uppfattning som av tidigare forskning påvisats hos elever, att uppgifter ska vara lösbara inom fem minuter (Schoenfeld, 1992). Resultaten från studie 3 troliggör att det krävs något mer än icke-rutinuppgifter för att bereda elever möjligheter att träna på kreativa matematiska resonemang. De uppfattningar elever har verkar inte i tillräcklig utsträckning bidra till att kreativa matematiska resonemang används. Liknande iakttagelser har gjorts av Ball och Bass (2003) som drar slutsatsen att en uppgifts utformning kan ha betydelse för elevens resonemang, men att utan en stöttande sociomatematisk norm riskerar möjligheterna att lära sig annat än imitativa resonemang att 
utebli. Dock kan inte en samstämmig bild målas upp av vilka hjälpbehov elever har, utan behoven, såväl som uppfattningarna elever har om matematik och matematiska resonemang är högst individuella. Schoenfeld (1985) diskuterar vad som krävs för att bli en god problemlösare och inkluderar bland annat nödvändiga förkunskaper, problemlösningsstrategier och uppfattningar om matematik som inkluderar annat än imitativa resonemang. Att elevers uppfattningar är individuella, kompletterar det som påvisats om hur kontext påverkar uppfattningarna (Fransisco, 2013).

Resultaten visar att såväl sättet som elever jobbar tillsammans som de metoder som lärare använder för att hjälpa elever framåt i uppgiftslösningen verkar kunna hämma användningen av kreativa matematiska resonemang. Elever guidar ofta varandra genom lösningar med syfte att skapa en redovisning med ett svar för läraren eller för jämförelse med facit i boken. Sällan stimuleras ett kreativt matematiskt resonemang i dessa samarbeten. Inte heller då lärare guidar elever vid uppgiftslösning har det visat sig att kreativa matematiska resonemang stimuleras. Det har även visat sig att lärare på sina prov inte ställer krav på kreativa matematiska resonemang i en större utsträckning (Palm et al., 2011). Lampert (1990) går så långt som att säga att lärare använder boken för att tillgodose behovet av regler och algoritmer så att eleverna i klassrummet kan komma fram till korrekta svar på angivna matematiska uppgifter. Det skapas alltför lite utrymme för matematiska resonemang i undervisningen, och detta beror delvis på att undervisning i procedurer fortfarande tar stort utrymme (Boesen et al., 2014; Hiebert, 2003). Ett av hindren för en sådan utveckling av undervisningen kan vara att lärare inte har den tid som krävs för att sätta sig in i, och djupare förstå betydelsen av förmågorna i ämnesplanen i matematik (Boesen et al., 2014). Att utgå från ämnesplanen i sin undervisning blir då en subjektiv handling. Det har visat sig att lärarna anser sig betona även förmågor som resonemang och problemlösning i undervisningen, trots att de i själva verket inte gör det (Boesen et al., 2014). I genomgångar för elevgrupper använder lärares oftast på uppgifter som är av rutinkaraktär för läraren. Detta medför att uppgifterna inte heller presenteras på ett arbetssätt där reflektion och argumentation kring metodval ingår (Berqqvist \& Lithner, 2012). Att lärare uttrycker att de betonar en bred matematisk kompetens, och inkluderar de förmågor som kommuniceras i ämnesplanen, men samtidigt delvis driver en annan undervisning exemplifierades tidigare i avsnitt 3.5.

Yackel och Hanna (2003) uttrycker behovet av sociomatematiska normer som mer tydligt inbegripa en bredare syn på matematiken, där inte procedurer och imitativa resonemang utgör det centrala. En förändring av de sociomatematiska normerna och de uppfattningar som uppvisas i klassrummet kan påverkas av arbetssätten som används och de ageranden som värdesätts. Skemp (1976) betonar att de aktiviteter som matematikutbildningen erbjuder tydligt ska leda mot ett lärandemål. Distinktionen mellan att kunna och att göra behöver alltså suddas ut (Hiebert et al., 1996). Möjligheterna till lärande är det som ska styra undervisningens utformning. Dewey (1929) lyfte fram en metod för att just integrera 
aktiviteter med möjligheter till lärande genom att introducera granskande undersökning (reflective inquiry), vilket innebär att identifierade problem driver undervisningen framåt med hjälp av elevengagemang där slutmålet är någon form av slutsats angående problemet. Utforskandet sker med lärande som mål snarare än att skapa en produkt $\mathrm{i}$ form av en lösning (Hiebert et al., 1996). Arbetet bör således koncentreras på att stötta eleverna $i$ att bygga upp en konceptuell förståelse, ett slags kunskapsnät eller en mental karta, snarare än att uppmuntra dem till att bli duktiga på att utföra rutinprocedurer (Hiebert \& Carpenter, 1992). Kunskap skapas av eleven och inte av läraren, även om den senare sannolikt och förhoppningsvis har en viktig roll i att stötta eleven i utvecklingen. Granskande undersökning kan stimulera till att ändamålsenliga algoritmer skapas av eleverna. Så istället för att använda algoritmer till att lösa matematiska problem, kan algoritmen bli ett av delmålen för eleven. I vissa fall krävs att algoritmer och fakta i större utsträckning automatiseras (Gravemeijer \& van Galen, 2003), så som till exempel multiplikationstabellen eller "tio-kamrater". I andra fall är det däremot rimligt att undervisningen inte nödvändigtvis strävar mot en formell algoritm, utan snarare en användbar, men mindre formell algoritm (Gravemeijer \& van Galen, 2003). Undervisningen har således såväl konceptuella som procedurella inslag. Cobb et al. (1993) lyfter fram granskande undersökning som ett gott exempel på undervisning som hjälper till att forma normer där möjligheter till lärande av mer än utantillkunskap och imitation utvecklas. Genom att erbjuda elever utmaningar, snarare än uppgifter som testar deras nuvarande kunskaper, och genom att stötta dem i arbetet med dessa kan en lärare visa på alternativa normer för undervisningens utformning. Explicita insatser från just läraren i klassrummet för att utveckla de sociomatematiska normerna i en önskvärd riktning är avgörande (Yackel \& Hanna, 2003). Hiebert et al. (1996) argumenterar för att förståelse skapas genom att undersökande arbetsmetoder används. Detta synliggörs i den sociala interaktionen som pågår i ett klassrum där förståelsen leder till ett utvecklat samtal där kunskapen delas och växer fram i ett samspel mellan eleverna och läraren. De aktiviteter som pågår i klassrummet medför att tankar och idéer utbyts, men innebär dessutom att strategier för att lösa matematiska problem formuleras och att eleverna kan bygga upp ett större och mer stabilt kunskapsnät samt att eleverna bildar sig nya uppfattningar om vad matematik är (Hiebert et al., 1996). Enligt Dweck (2007) finns det elever som anser att intelligens inte alls kan byggas upp, utan antingen finns eller inte, och att detta leder till att eleverna håller uppe skenet genom att lösa enklare rutinuppgifter utan utmaningar och utan att jobba för en djupare förståelse. Det blir då viktigt att för eleverna belysa vikten av en helhetssyn på den matematiska kunskapen snarare än ett korrekt svar på en uppgift.

Hiebert et al. (1996) föreslår ett antal punkter att beakta då undervisningen planeras. Den första punkten innebär att eleverna behöver få möjlighet att utforska matematiken med hjälp av problem, snarare än att en lärare visar på lösningen till ett problem. Den andra punkten handlar om att eleverna ska få möjlighet att göra problemen till sina egna, för att på så sätt också kunna knyta dem till sina förkunskaper och sitt unika kunskapsnät för att på bästa sätt 
komplettera nätet med den bonuseffekt problemlösning sagt erbjuda i form av kunskap. Detta innebär nödvändigtvis inte att det alltid är eleverna som ska formulera problemen, utan denna process kan initieras av såväl lärare som elever. Den sista punkten betonar vikten av att undervisningen syftar till att utveckla såväl den kognitiva kunskapen som elevernas uppfattningar om matematik. En undervisning baserad på öppna uppgifter med möjligheter till egen reflektion beskrivs av Boaler (1998) som framgångsrik. Boaler (1998) visar på skillnaden mellan två undervisningsmodeller och utfallet av dessa. Hon beskriver en situation där skolan med en traditionell, läroboksbaserad undervisning fostrade elever som ansåg att matematiken till största delen handlar om att komma ihåg. Eleverna jobbade mycket enskilt och i sin egen takt utifrån lärobokens beskrivningar av metoder och med individuellt stöd av läraren. Dessa elever presterade mindre bra med avseende på de nationella GCSE- (General Certificate of Secondary Education) prov som de allra flesta 16-åringar genomför i Storbritannien, och eleverna uttryckte en frustration över att inte kunna applicera sina algoritmer i de till synes nya situationer som proven krävde. På den andra skolan å andra sidan fick eleverna möjlighet att jobba med större, öppna uppgifter eller projekt, där eleverna uppmuntrades att resonera sig fram till egna lösningar och reflektera över sina metoder. På detta sätt mötte eleverna ett behov av matematiken och använde då läraren som en resurs i sitt arbete med projektet. Eleverna på denna skola ansåg att matematik handlade om att kunna vara flexibel och använda sig av olika metoder beroende på situationen och på att tänka och reflektera. Just detta ansåg de också vara grunden till de relativt sett goda provresultat de presterade. De tyckte inte att de nya situationer som uppgifterna på provet presenterade innebar lika stora problem som eleverna på den första skolan gjorde.

Tidigare forskning har betonat vikten av en aktiv insats av såväl elever som lärare för att öka möjligheterna till lärande (Webb \& Mastergeorge, 2003). Till exempel är det viktigt att erbjuda elever möjligheter att själva skapa en lösningsmetod till uppgiften. Elever bör ha som mål att alltid förstå och utifrån detta också ställa precisa frågor. Hiebert och Wearne (1993) har tidigare visat att det är fruktbart att stimulera eleverna till att finna alternativa lösningar till de matematiska problem de ställs inför, snarare än att lösa flera olika problem på ett likartat sätt. Denna stimulans kan komma från läraren i form av frågor som syftar till att få eleverna att beskriva och förklara sina lösningar. Stein, Engle, Smith och Hughes (2008) preciserar de krav som är rimliga att ställa på lärare för att optimera ett undersökande arbetssätt. För att kunna förbereda gemensamma diskussioner med utgångspunkt i elevlösningar är det viktigt att lärare aktivt observerar elevernas arbete. Det är i diskussionen väsentligt att lyfta fram och jämföra olika lösningar till en uppgift och på så sätt stötta eleverna till en djupare förståelse.

Det krävs även ett större engagemang och en bättre organisation kring på vilket sätt som elever samarbetar (Fuchs et al., 1997). Då elever jobbar i grupp finns en risk att elever med stöd av sina kompisar löser uppgiften utan större förståelse, men inte inser detta. Det är således väsentligt att hjälpa eleverna att själva reflektera över sin förståelse (Webb \& 
Mastergeorge, 2003). Genom att betona vikten av ett gemensamt ansvar för lösningen till gruppuppgifter förmedlar även läraren vilken syn på matematisk kunskap han har. Cobb et al., (1993) ger exempel på hur detta kan ske genom att läraren genom frågor inkluderar samtliga gruppmedlemmar. Läraren i exemplet inleder också en metadiskussion kring hur grupperna bör sträva efter att samtliga i gruppen förstår den gemensamma lösningen. En liknande metadiskussion kring skriftliga redovisningar som ett stöd för en tanke process snarare än som en produkt för läraren är en tänkbar väg mot utvecklade sociomatematiska normer.

Den medvetenhet som krävs för att lärare ska kunna utveckla sin undervisning i denna riktning behöver byggas upp på skolorna, exempelvis genom riktade fortbildningsinsatser, men inte minst också genom ett kontinuerligt arbete, där alla kollegor på skolan medverkar i en gemensam insats. Lärare bör få stöd med att tolka och jobba med styrdokumenten (Boesen et al., 2014). Det stöd som behövs kan vara tid eller kunskap eller rent av ett ökat intresse för att jobba med utvecklingsarbete i skolan. Här kan en skolledning spela en central roll genom att visa på incitament i form av till exempel en positiv kunskapsutveckling och genom att ge möjligheter till att diskutera de goda exempel från forskningen, som finns. Även lärarutbildningen har en viktig roll $\mathrm{i}$ att med blivande lärare diskutera vad som krävs för att bygga upp en bred matematisk kompetens hos eleverna.

\subsection{Läromedlen och läromedelsanvändningen}

Elevers uppfattningar om matematik såväl som de sociomatematiska normer som råder i klassrummet påverkas i hög utsträckning av de aktiviteter som används i undervisningen (Lampert, 1990). De aktiviteter som genomförs hämtas inte sällan från läroboken (Schmidt et al., 2001). En följd av detta blir att också möjligheterna till lärande påverkas av hur läroboken är utformad och hur den används. För att utveckla våra elevers utbildning krävs utökade möjligheter till lärande och detta innebär bland annat uppbyggnaden av sociomatematiska normer som tar stöd i att matematik är mer än procedurer och utantillinlärning (Schoenfeld, 2012). Utvecklade läromedel kan hjälpa till att förändra undervisningen i önskad riktning (Herbal-Eisenmann, 2007). Arbetet med att skapa sociomatematiska normer som inkluderar ett större perspektiv på matematiken kan få ett slagkraftigt argument med hjälp av boken. Resultaten av analysen av läromedel visar att andelen uppgifter som kräver ett kreativt matematiskt resonemang är liknande i de tolv ländernas böcker. En hypotetisk förklaring till denna relativa likhet är den djupt rotade matematiska tradition som är global och som påverkar läromedlen i mycket hög grad. Förutsatt att de analyserade böckerna är representativa för respektive land indikerar resultaten att läromedlens utformning inte är den enda bidragande faktorn till de resultat som påvisats i till exempel TIMSS- och PISA (Programme for International Student Assessment)-studierna. Sociomatematiska normer är som i tidigare avsnitt diskuterats avhängigt av en mängd faktorer, varav läroboken är en. I genomsnitt ungefär var tionde uppgift $\mathrm{i}$ de analyserade läromedlen krävde ett kreativt matematiskt resonemang. En iakttagelse som bör beaktas i sammanhanget är också att de flesta uppgifter som enligt kategoriseringen bedömts kräva ett kreativt matematiskt 
resonemang, har lösningar som också till viss del består av algoritmhantering. I uppgifter som däremot kan lösas genom imitativa resonemang saknas helt de kreativa matematiska resonemangen. Om även denna aspekt beaktas kan resultaten beskrivas som att i det närmaste $100 \%$ av uppgifterna erbjuder möjligheter att träna på algoritmer och mer procedurella kunskaper, medan ungefär 10-20 \% av uppgifterna erbjuder möjligheter att träna på kreativa matematiska resonemang. Beaktas bör även att uppgifter som kräver kreativa matematiska resonemang återfinns avsevärt mindre frekvent i den grupp av uppgifter eleverna först stöter på inom varje nytt avsnitt. Då resultaten av elevernas arbete med läroboksuppgifter visar att eleverna i den svenska gymnasieskolan främst jobbar med de första, enklare uppgifterna i boken är det intressant att poängtera att andelen uppgifter som kräver ett kreativt matematiskt resonemang i denna grupp är ungefär $5 \%$ enligt analysen. I flera av de analyserade läromedlen finns det fler uppgifter än vad som kan anses rimligt för eleverna att jobba med, vilket antyder att ett uppgiftsurval görs, antingen av den enskilda eleven och/eller av läraren.

Att flera läromedel utifrån sin egen beteckning på uppgifterna särskiljer på till exempel resonemangs- eller problemlösningsuppgifter och färdighetsuppgifter, och där de senare i samtliga fall i boken föregår de tidigare, indikerar en syn på progression där just färdighetsträning är det initiala i lärprocessen, och där några men inte nödvändigtvis alla elever når resonemangsuppgifterna. I kunskapskraven för matematik $\mathrm{i}$ den svenska gymnasieskolan framgår dock att matematiskt resonemang är en förmåga som krävs för att uppnå för det lägsta godkända betyget såväl som det högsta betyget, dock med olika kvalitet (Skolverket, 2011a). Att uppgifter av undersökande karaktär särskiljs och potentiellt riskerar att uteslutas för vissa elever påvisar möjligen ytterligare en aspekt att beakta då läromedel utformas.

Den aktuella läromedelsstudien, likväl som andra (Lithner, 2004) indikerar att läromedel använda i svensk undervisning inte med självklarhet fungerar som ett stöd i utvecklingen av sociomatematiska normer där större utrymme ges åt en konceptuell kunskap, vilket dock inte utesluter att sådana läromedel kan finnas. Inte heller analysen av de internationella läromedlen ger fog för att säga att de kan fungera som ett gott stöd i utvecklingen av sådana sociomatematiska normer. Detta indikeras även av tidigare läromedelsforskning. Till exempel anser Fan och Zhu (2007) att läromedel från såväl Singapore som Kina och USA uppvisar brister i sättet de presenterar problemlösning på. Vincent och Stacey (2008) drar slutsatsen att flera av de australiensiska läromedel de analyserat inkluderar en alltför stor andel uppgifter av enkel procedur- och repetitionskaraktär. Herbal-Eisenmann (2007) presenterar en liknande bild avseende läromedel från USA som inte lyckas förmedla en bild av en matematik som innefattar kreativa matematiska resonemang. Schmidt et al. (2001) visar att flertalet av 34 länders läromedel innehöll färre än $15 \%$ komplexa uppgifter, där en komplex uppgift definieras som en uppgift som kräver problemlösnings- och resonemangsförmåga för att lösas. Schmidt med kollegors resultat är i linje med resultaten från studie 1. Betydelsen av 
dessa resultat kan också förstärkas av Henningsen och Stein (1997) som sett att uppgifter som kräver ett eget tänkande från eleven för att lösas, är de uppgifter som oftast av lärare och elever behandlas på ett sätt så att de konceptuella kraven avtar. Liknande resultat har också påvisats av den analys av klassrumsarbete som gjordes i samband med TIMSS 1999, där många av de uppgifter som bedömdes stimulera till att skapa en konceptuell förståelse löstes på procedurella sätt (Hiebert et al., 2003). Detta kan tolkas som att möjligheterna att lära sig annat än imitativa resonemang avtar ytterligare. Faktorer som visat sig avgörande för att behålla de möjligheter till lärande som uppgiften sannolikt avsett är bland annat elevens förförståelse och den tid som avsätts för uppgiften (Henningsen \& Stein, 1997). Dessutom har som tidigare poängterats lärarens stöd stor betydelse, och det är viktigt att stödet består av att skapa en förståelse och att med hjälp av uppgiften stärka elevens kunskapsnät, snarare än att fokusera på att presentera en lämplig algoritm (Henningsen \& Stein, 1997).

Stacey och Vincent (2009) utvecklar resonemanget kring australiensiska läromedel där presentationerna kan betraktas som en manual för hur de efterföljande uppgifterna ska lösas. Lithner och Palm (2010) drar slutsatsen att lärare förväntar sig att läromedel ska fungera som en manual till hur uppgifter löses. I en svensk kontext beror detta enligt Lithner och Palm delvis på hur lektionstiden till stor del används, där individuellt arbete med uppgifter prioriteras. Just uppgifterna utgör en stor del av ett läromedel i matematik och influerar sannolikt elevers och lärares uppfattning om ämnet. Så omfattningen av uppgifter med möjligheter till lärande av olika typer av förmågor, och olika typer av krav är viktigt. Schoenfeld (1992) uttrycket en oro för den ackumulerade effekt de tusentals uppgifter elever löser under sin skolgång, och som förväntas kunna lösas på någon enstaka minut, och med fördel genom memorerade algoritmer. Elevernas uppfattning om matematik måste utvecklas så att exempelvis kreativa matematiska resonemang blir en mer naturlig del av ämnet för dem. Läromedlen behöver inkludera mer material med syfte att erbjuda möjligheter till lärande av en bred matematisk kompetens, på samtliga svårighetsnivåer, och på ett lättillgängligt sätt. Då eleverna sällan tar stöd av läroboken, vare sig i ett imitativt eller kreativt matematiskt resonemang är det rimligt att tycka att dessutom läromedelsförlagen ytterligare bör beakta på vilket sätt de strukturerar och presenterar innehållet.

Utifrån en syn på undervisningen där ett undersökande arbetssätt används föreslår Stein och Lane (1996) att uppgifter som möjliggör olika typer av lösningar och olika typer av representationsformer samt ställer krav på eleverna att också förklara sitt arbete används. Dessa typer av uppgifter beskriver Stein och Lane (1996) som en god grund för ett klassrumsarbete som syftar till att skapa möjligheter för eleverna att lära sig mer än utantillkunskaper så som till exempel att resonera kreativt matematiskt. Det är rimligt att anta att denna typ av uppgifter också kan presenteras av en lärobok. Andelen uppgifter som kan lösas med imitativa resonemang bör då kunna minska, för som Hiebert (2003) påtalar krävs inte 
lika mycket övning för att minnas och kunna använda en procedur om man också förstår hur och varför den fungerar.

Lösningen ligger dock inte enbart i utvecklade läromedel, utan utifrån lärobokens utformning och vilka kunskapskrav som ställs på eleverna blir det viktigt att använda läroboken medvetet och reflekterande, så att de lärandemål som definierats också kan uppnås. För att detta ska bli verklighet måste reella möjligheter för lärare att hantera även denna del av sitt arbete på ett tillfredställande sätt. Trots den betydelse läroboken har i matematikundervisningen visar det faktum att den också används på vitt skilda sätt (Rezat \& Strässer, 2014) att också möjligheterna till lärande kan variera högst påtagligt. De styrdokument som reglerar utbildningen i Sverige och många andra länder i världen baseras på en syn att matematisk kunskap består av mer än procedurer. På en systemnivå visar alltså en avsedd läroplan vad som forskningen betonat som avgörande för att bättre rusta våra elever med en bred matematisk kompetens. Fan och Zhu (2007) har dock funnit tydliga skillnader mellan vad styrdokument och läromedel i såväl Singapore, Kina som USA tar upp. Liknande resultat presenteras avseende den svenska skolan av Jablonka och Johansson (2010). Detta ställer krav på att läromedlen väljs ut och används med omsorg. I en undersökning gjord av den lärarfackliga tidskriften Skolvärlden där 1500 svenska lärare deltog (Stridsman, 2014, nov) framkom att $79 \%$ av de tillfrågade upplevde att de inte hade tillräckligt med tid för att kvalitetsgranska, värdera och välja läromedel. Tidigare fanns i Sverige en central granskning av läromedel som i alla fall till viss del bemötte problemet med tidsbrist hos lärarna. Dock tror jag att genom möjligheten att välja läromedel skapas en verklig möjlighet för lärarna att också utforma sin undervisning utifrån sina egna förutsättningar och visioner. Men för att lärarna ska kunna göra medvetna val baserade på dessa förutsättningar och visioner och dessutom på de styrdokument som ligger till grund för undervisningen krävs såväl tid som kunskap. Lärare måste få en möjlighet att under ordnade fortbildningsformer eller under sin utbildning träna sig i att använda undervisningsmaterial på ett medvetet sätt så att möjligheter till lärande ges för de förmågor som enligt forskningen och även styrdokumenten ligger till grund för en bred matematisk kompetens. Detta kan till exempel innebära diskussioner kring och medvetandegörande av betydelsen av urval av läromedel och hur dessa används. Med tillgång till läromedel som inkluderar en bredare syn på matematiken och som bereder möjligheter till lärande av såväl procedurell som konceptuell kunskap skapas en större potential för ökade möjligheter till lärande, i en urvalsprocess. Men likväl kan det innebära en träning i att bygga upp undervisningen på fler källor, där läroboken kan vara en del, och där återigen en bred matematisk kompetens får utgöra målet för undervisningen.

\subsection{Sammanfattande slutsatser}

Utifrån den förda diskussionen ovan önskar jag sammanfatta och poängtera några av de möjliga implikationer på undervisningen i matematik som framkommit i och med arbetet med de tre studierna som ingår i denna avhandling. 
- Det behövs ett stöd för lärare att tolka styrdokument och att jobba med sin undervisning med en bred matematisk kompetens som mål.

- En undervisning som i ökad utsträckning baseras på problem där eleverna själva får utforska matematiken, och där läraren kan stötta eleverna $i$ en process, snarare än att presentera färdiga algoritmer är viktig.

- Uppfattningen om matematik hos eleverna är en annan väsentlig faktor att beakta, och metadiskussioner om matematiken i klassrummet kan främja utvecklingen av sociomatematiska normer som på ett bra sätt stöttar det mål som tidigare presenterats som en bred matematisk kompetens.

- Även utvecklade läromedel som skapar bättre förutsättningar för lärare att med hjälp av läroboken skapa goda möjligheter för denna typ av lärande är värdefullt. Andra typer av aktiviteter som mer tydligt betonar vikten av en konceptuell förståelse blir då viktiga att inkludera $i$ läromedlen. I linje med detta kan även andelen proceduruppgifter sannolikt minskas.

- Eleverna använder sällan läroboken annat än som uppgiftsbank med ett medföljande facit. Då läromedel utformas bör beaktas hur det är önskvärt att eleverna använder böckerna som stöd i en lärprocess.

- I och med den indelning av uppgifter som läroboksförfattarna gör förenklas möjligheterna att göra urval där en viss typ av uppgifter helt utesluts. Detta indikerar att det bör noga beaktas vilket epitet som sätts på uppgifterna i en lärobok och också uppgifternas inbördes ordningsföljd.

\subsection{Fortsatt forskning}

Utifrån diskussionen ovan kan flera frågor formuleras vars svar skulle vara en hjälp på vägen mot en utvecklad syn på matematiken. Väsentligt i mycket av detta är hur skolan kan stimulera till lärandet av en bred matematisk kompetens, där till exempel kreativa matematiska resonemang har en central roll. Mycket av utvecklingsarbetet i klassrummet är lärarens ansvar. Frågor att beakta i detta sammanhang är då:

- Vilka begränsningar lärare känner då en mer konceptuell undervisning ska iscensättas?

- På vilket sätt stöttas lärarna bäst då undervisningen ska utvecklas för att inkludera mer kreativa matematiska resonemang och problemlösning?

- Vilka parametrar blir avgörande då eleverna jobbar i grupp med uppgifter med avseende att lösa problem och lära sig resonera matematiskt?

I och med läromedlens centrala roll i matematikklassrummet kan de sociomatematiska normerna och det sätt på vilket undervisningen bedrivs påverkas med hjälp av dessa. Frågor att beakta då utvecklade läromedel efterfrågas är:

- Vilka uppgifter fungerar $\mathrm{i}$ en läromedelskontext med en kontinuitet och en ackumulerad effekt i lärandet, och hur ser läroboken i övrigt ut i relation till uppgifterna? 
- Hur kan lärarhandledningar kopplade till läromedel på ett bra sätt stötta lärare till en utvecklad undervisning med fokus på en bred matematisk kompetens?

För att ytterligare nyansera elevers möjligheter till lärande är det viktigt att beakta såväl läroboken och hur den används i undervisningen, som annat undervisningsmaterial och dess användning. En fråga relaterad till detta ämne och som bör beaktas är:

- På vilket sätt används annat undervisningsmaterial och vilka möjligheter till lärande erbjuder de i förhållande till hur de används?

Samtliga de studier som ingår i denna avhandling har undersökt möjligheterna till lärande $\mathrm{i}$ gymnasieskolan. En bild av matematikundervisningen i den kontexten har presenterats, men vad som sker i de tidigare åldrarna har inte beaktats. Den undervisning som bedrivs på gymnasiet bygger på det som sker på grundskolan. Så för att utveckla matematikundervisningen krävs att vi frågar oss hur undervisningen ser ut även i grundskolan:

- Vilka uppfattningar om matematik och matematiska resonemang har elever i grundskolan, och vilka resonemang använder eleverna i grundskolan i relation till dessa uppfattningar?

- Vilka möjligheter till lärande med avseende på matematiska resonemang erbjuder grundskoleläromedel i matematik, beaktandes hur de används? 


\section{Referenser}

Ball, D. L., \& Bass, H. (2003). Making mathematics reasonable in school. I J. Kilpatrick, W. G. Martin \& D. Schifter, (Red.), A research companion to the principles and standards for school mathematics (s. 27-44). Reston, VA: National Council of Teachers of Mathematics.

Bauersfeld, H. (1980). Hidden dimensions in the so-called reality of a mathematics classroom. Educational Studies in Mathematics, 11(1), 23-41.

Bergqvist, T. \& Lithner, J. (2012). Mathematical reasoning in teachers' presentations. Journal of Mathematical Behavior, 31(2), 252-269.

Bergqvist, T., Lithner, J., \& Sumpter, L. (2008). Upper secondary students' task reasoning. International Journal of Mathematical Education in Science and Technology, 39(1), 112.

Boaler, J. (1998). Open and closed mathematics: Student experiences and understandings. Journal for Research in Mathematics Education, 29(1), 41-62.

Boesen, J., Helenius, O., Bergqvist, E., Bergqvist, T., Lithner, J., Palm, T. \& Palmberg, B. (2014). Developing mathematical competence: From the intended to the enacted curriculum. The Journal of Mathematical Behaviour, 33(1), 72-87.

Boesen, J., Lithner, J., \& Palm, T. (2010). The relation between types of assessment tasks and the mathematical reasoning students use. Educational Studies in Mathematics, 75(1), 89105 .

Brousseau, G. (1997). Theory of didactical situations in mathematics. Dordrecht: Kluwer Academic Publishers.

Burstein, L. (1993). Studying learning, growth, and instruction cross-nationally: Lessons learned about why and why not engage in cross-national studies. I L. Burstein (Red.) The IEA Study of Mathematics III: Student Growth and Classroom Processes, xxvii-xlix. New York: Pergamon Press.

Cobb, P. (1994). Where is the mind? constructivist and sociocultural perspectives on mathematical development. Educational Researcher, 23(7), 13-20.

Cobb, P., Wood, T., \& Yackel, E. (1993). Discourse, mathematical thinking, and classroom practice. I E. A. Forman, N. Minick \& C. A. Stone (Red.), Contexts for learning: Sociocultural dynamics in children's development. (s. 91-119). New York, NY: Oxford University Press.

Dewey, J. (1929). The quest for certainty. Oxford, England: Minton, Balch.

Doyle, W. (1983). Academic work. Review of Educational Research, 53(2), 159-199.

Dweck, C. S. (2007). Boosting achievement with messages that motivate. Education Canada, 47(2), 6-10. 
Engelbrecht, J., Bergsten, C., \& Kågesten, O. (2009). Undergraduate students' preference for procedural to conceptual solutions to mathematical problems. International Journal of Mathematical Education in Science and Technology, 40(7), 927-940.

Fan, L., \& Zhu, Y. (2007). Representation of problem-solving procedures: A comparative look at China, Singapore, and US mathematics textbooks. Educational Studies in Mathematics, 66(1), 61-75.

Floden, R. E. (2002). The measurement of opportunity to learn. I A. C. Porter \& A. Gamoran (Red.), Methodological advances in cross-national surveys of educational achievement (s. 231-266). Washington, DC: National Academy Press.

Francisco, J. (2013). The mathematical beliefs and behavior of high school students: Insights from a longitudinal study. The Journal of Mathematical Behavior, 32(3), 481-493.

Fuchs, L. S., Fuchs, D., Hamlett, C. L., Phillips, N. B., Karns, K., \& Dutka, S. (1997). Enhancing students' helping behavior during peer-mediated instruction with conceptual mathematical explanations. The Elementary School Journal, 97, 223-249.

Furinghetti, F., \& Morselli, F. (2009). Every unsuccessful problem solver is unsuccessful in his or her own way: Affective and cognitive factors in proving. Educational Studies in Mathematics, 70(1), 71-90.

Gravemeijer, K. \& van Galen, F. (2003). Facts and algorithms as products of students' own mathematical activity. I J. Kilpatrick, W. G. Martin \& D. Schifter, (Red.), A research companion to the principles and standards for school mathematics (s. 114-122). Reston, VA: National Council of Teachers of Mathematics.

Greer, B., Verschaffel, L., \& de Corte, E. (2002). 'The answer is really 4.5': Beliefs about word problems. I G. C. Leder, E. Pehkonen \& G. Törner (Red.), Beliefs : A hidden variable in mathematics education? (s. 271-292). Dordrecht: Kluwer Academic Publishers.

Henningsen, M., \& Stein, M. K. (1997). Mathematical tasks and student cognition: Classroom-based factors that support and inhibit high-level mathematical thinking and reasoning. Journal for Research in Mathematics Education, 28(5), 524-549.

Herbel-Eisenmann, B. (2007). From intended curriculum to written curriculum: Examining the "voice" of a mathematics textbook. Journal for Research in Mathematics Education, 38(4), 344-369.

Hiebert, J. (2003). What research says about the NCTM standards. I J. Kilpatrick, W. G. Martin \& D. Schifter, (Red.), A research companion to the principles and standards for school mathematics (s. 5-23) Reston, VA: National Council of Teachers of Mathematics.

Hiebert, J., \& Carpenter, T. P. (1992). Learning and teaching with understanding. I D. A. Grouws (Red.), Handbook for research on mathematical teaching and learning (s. 6597). New York, NY: Macmillan. 
Hiebert, J., Carpenter, T. P., Fennema, E., Fuson, K., Human, P., Murray, H., ... Wearne, D. (1996). Problem solving as a basis for reform in curriculum and instruction: The case of mathematics. Educational Researcher, 25(4), 12-21.

Hiebert, J., Gallimore, R., Garnier, H., Givvin, K. B., Hollingsworth, H., Jacobs, J., ... Stigler, J. (2003).Teaching mathematics in seven countries: Results from the TIMSS 1999 video study. Washington, DC: U.S. Government Printing Office.

Hiebert, J., \& Grouws, D. (2007). The effects of classroom mathematics teaching on students learning. I F. K. Lester (Red.), Second handbook of research on mathematics teaching and learning : A project of the national council of teachers of mathematics (s. 371-404). Charlotte, NC: National Council of Teachers of Mathematics; Information Age Publishing.

Hiebert, J., \& Lefevre, P. (1986). Conceptual and procedural knowledge in mathematics: An introductory analysis. I J. Hiebert (Red.), Conceptual and procedural knowledge: The case of mathematics (s. 1-27). Hillsdale, NJ: Erlbaum.

Hiebert, J., \& Wearne, D. (1993). Instructional tasks, classroom discourse, and students' learning in second-grade arithmetic. American Educational Research Journal. 2(30), 393-425.

Jablonka, E., \& Johansson, M. (2010). Using texts and tasks: Swedish studies on mathematics textbooks. I B. Sriraman (Red.), The first sourcebook on nordic research in mathematics education : Norway, Sweden, Iceland, Denmark, and contributions from Finland (s. 363372). Charlotte, NC: Information Age Publishing.

Jonsson, B., Norqvist, M., Lithner, J., \& Liljekvist, Y. (2014). Learning mathematics through algorithmic and creative reasoning. Journal of mathematical behavior, 36, 20-32.

Kloosterman, P. (2002). Beliefs about mathematics and mathematics learning in the secondary school: Measurement and implications for motivation. I G. C. Leder, E. Pehkonen \& G. Törner (Red.), Beliefs: A hidden variable in mathematics education? (s. 247-269). Dordrecht: Kluwer Academic Publishers.

Lampert, M. (1990). When the problem is not the question and the solution is not the answer: Mathematical knowing and teaching. American Educational Research Journal, 27(1), 29-63.

Lithner, J. (2003). Students' mathematical reasoning in university textbook exercises. Educational Studies in Mathematics, 52(1), 29-55.

Lithner, J. (2004). Mathematical reasoning in calculus textbook exercises. Journal of Mathematical Behavior, 23(4), 405-427.

Lithner, J. (2008). A research framework for creative and imitative reasoning. Educational Studies in Mathematics, 67(3), 255-276.

Lithner, J., \& Palm, T. (2010).Learning difficulties and mathematical reasoning. In B. Sriraman (Ed.), The first sourcebook on nordic research in mathematics education : 
Norway, Sweden, Iceland, Denmark, and contributions from Finland (s. 283-298). Charlotte, NC: Information Age Publishing.

McLeod, D. B. (1992). Research on affect in mathematics education: A reconceptualization. In D. A. Grouws (Red.), Handbook for research on mathematical teaching and learning (s. 575-596). New York, NY: Macmillan.

Mullis, I. V. S., Martin, M. O., Foy, P., Arora, A. (2012). TIMSS 2011 International Results in Mathematics. Chestnut Hill, MA: Boston College, TIMSS and PIRLS International Study Center.

Mullis, I. V. S., Martin, M. O., Foy, P., Olson, J. F., Preuschoff, C., Erberber, E., ... Galia, J. (2008). TIMSS 2007 International Mathematics Report - Findings from IEA's trends in international Mathematics and Science Study at the fourth and eighth grades. Chestnut Hill, MA: Boston College, TIMSS and PIRLS International Study Center.

Mullis, I. V. S., Martin, M. O., Ruddock, G. J., O'Sullivan, C. Y. \& Preuschoff, C. (2009). TIMSS 2011 assessment frameworks. Chestnut Hill, MA: Boston College, TIMSS and PIRLS International Study Center.

Niss, M. (2003). Mathematical competencies and the learning of mathematics: The Danish KOM project. Third Mediterranean Conference on Mathematics Education Athens, Greece. 115-124.

Op't Eynde P., de Corte, E. \& Verschaffel, L., (2002). Framing students' mathematics-related beliefs. I G. C. Leder, E. Pehkonen \& G. Törner (Red.), Beliefs : A hidden variable in mathematics education? (s. 13-37). Dordrecht: Kluwer Academic Publishers.

OECD (2014). PISA 2012 results in Focus. What 15-year-olds know and what they can do with what they know. Paris: OECD Publishing.

Palm, T., Boesen, J., \& Lithner, J. (2011). Mathematical reasoning requirements in Swedish upper secondary level assessments. Mathematical Thinking and Learning: An International Journal, 13(3), 221-246.

Rezat, S. (2012). Interactions of teachers' and students' use of mathematics textbooks. I G. Gueudet, B. Pepin \& L. Trouche (Red.), From text to 'lived' resources (s. 231-245). Dordrecht: Springer Science+Business Media B.V.

Rezat, S., \& Strässer, R. (2012). From the didactical triangle to the socio-didactical tetrahedron: Artifacts as fundamental constituents of the didactical situation. ZDM - The International Journal of Mathematics Education, 44(5), 641-651.

Rezat, S., \& Strässer, R. (2014). Mathematics Textbooks and How They Are Used. In P. Andrews \& T. Rowland (Red), Master Class in Mathematics Education. International Perspectives on Teaching and Learning. (pp. 51-62). New York: Bloomsbury.

Sanaghan T., Pennel J., Munro C., Ford C., Dalton J. \& Walker E. (2007). Scottish Secondary Mathematics R3. Essex: Heinemann 
Schmidt, W. (2012). Measuring content through textbooks: The cumulative effect of middleschool tracking. I G. Gueudet, B. Pepin \& L. Trouche (Red.), From text to 'lived' resources (s. 143-160). Dordrecht: Springer Science+Business Media B.V.

Schmidt, W. H., McKnight, C. C., Houang, R. T., Wang, H., Wiley, D. E., Cogan, L. S. \& Wolfe, R. G. (2001). Why schools matter: A cross-national comparison of curriculum and learning. San Francisco: The jossey-bass education series

Schoenfeld, A. H. (1985). Mathematical problem solving. Orlando: Academic Press.

Schoenfeld, A. H. (1992). Learning to think mathematically: Problem solving, metacognition, and sense making in mathematics. I D. A. Grouws (Ed.), Handbook for research on mathematical teaching and learning (s. 334-370). New York, NY England: Macmillan Publishing Co, Inc.

Schoenfeld, A. H. (2012). Problematizing the didactic triangle. ZDM - The International Journal of Mathematics Education, 44(5), 587-599.

Sfard, A. (1991). On the dual nature of mathematical conceptions: Reflections on processes and objects as different sides of the same coin. Educational Studies in Mathematics, 22(1), 1-36.

Sfard, A., \& Linchevski, L. (1994). The gains and the pitfalls of reification: The case of algebra. Educational Studies in Mathematics, 26(2-3), 191-228.

Shield, M., \& Dole, S. (2013). Assessing the potential of mathematics textbooks to promote deep learning. Educational Studies in Mathematics, 82 (2), 183-199

Skemp, R.R. (1976). Relational understanding and instrumental understanding. Mathematics teaching, 77, 20-26.

Skolverket. (2003). Lusten att lära - med fokus på matematik. No. 221. Stockholm: Fritz.

Skolverket (2011a).Läroplan, examensmål och gymnasiegemensamma ämnen för gymnasieskola 2011. Stockholm: Fritzes.

Skolverket. (2011b). Ämnesplan - matematik. alla kommentarer. Stockholm: Skolverket. Hämtad (16/1-2015) http://www.skolverket.se/laroplaner-amnen-och-kurser/ gymnasieutbildning/gymnasieskola/mat?tos=gy\&subjectCode=MAT\&lang=svhttp:// www.skolverket.se/laroplaner-amnen-och-kurser/gymnasieutbildning/gymnasieskola/ mat?tos $=$ gy\&subjectCode $=$ MAT $\&$ lang $=$ sv

Skolverket. (2012). Upper secondary school 2011. Stockholm: Fritzes.

Stacey, K., \& Vincent, J. (2009). Modes of reasoning in explanations in Australian eighthgrade mathematics textbooks. Educational Studies in Mathematics, (3), 271.

Stridsman, S. (2014, nov). Läromedelslotteriet. Skolvärlden, 9, s. 29-34. 
Stein, M. K., Engle, R. A., Smith, M. S., \& Hughes, E. K. (2008). Orchestrating productive mathematical discussions: Five practices for helping teachers move beyond show and tell. Mathematical Thinking and Learning: An International Journal, 10(4), 313-340.

Stein, M. K., \& Lane, S. (1996). Instructional tasks and the development of student capacity to think and reason: An analysis of the relationship between teaching and learning in a reform mathematics project. Educational Research \& Evaluation, 2(1), 50.

Stein, M. K., Remillard, J., \& Smith, M. S. (2007). How curriculum influences student learning. I F. K. Lester (Red.), Second handbook of research on mathematics teaching and learning : A project of the national council of teachers of mathematics (s. 319-369). Charlotte, NC: National Council of Teachers of Mathematics; Information Age Publishing.

Sumpter, L. (2013).Themes and interplay of beliefs in mathematical reasoning. International Journal of Science and Mathematics Education, 11(5), 1115-1135.

Törnroos, J. (2005). Mathematics textbooks, opportunity to learn and student achievement. Studies in Educational Evaluation, 31(4), 315-327.

Valverde G. A., Bianchi L. J., Wolfe R. G., Schmidt W. H. och Houang R. T. (2002). According to the book: Using TIMSS to investigate the translation of policy into practice through the world of textbooks. Dordrecht, Netherlands: Kluwer Academic Publishers.

Vetenskapsrådet. (2011). God forskningssed. (No. 1:2011). Stockholm: Vetenskapsrådet.

Vincent, J., \& Stacey, K. (2008). Do mathematics textbooks cultivate shallow teaching? applying the TIMSS video study criteria to australian eighth-grade mathematics textbooks. Mathematics Education Research Journal, 20(1), 82-107.

Vygotsky, L. S., (1978). Mind in society : The development of higher psychological processes. Cambridge, MA: Harvard University Press.

Wai Keung, C. (2013). Discovering Mathematics 1A. Singapore: Star publishing Pte Ltd

Webb, N. M., \& Mastergeorge, A. (2003). Chapter 4: Promoting effective helping behavior in peer-directed groups. International Journal of Educational Research, 39 (1-2), 73-97.

Yackel, E., \& Cobb, P. (1996).Sociomathematical norms, argumentation, and autonomy in mathematics. Journal for Research in Mathematics Education, 27(4), 458-77.

Yackel, E., Hanna, G. (2003). Reasoning and proof. I J. Kilpatrick, W. G. Martin \& D. Schifter, (Red.), A research companion to the principles and standards for school mathematics (s. 227-236). Reston, VA: National Council of Teachers of Mathematics.

Yackel, E., \& Rasmussen, C. (2002). Beliefs and norms in the mathematics classroom. I G. C. Leder, E. Pehkonen \& G. Törner (Red.), Beliefs : A hidden variable in mathematics education? (s. 313-330). Dordrecht: Kluwer Academic Publishers. 



\section{DEL 2 - STUDIERNA}





\section{Articles}

The articles associated with this thesis have been removed for copyright reasons. For more details about these see:

http://urn.kb.se/resolve?urn=urn:nbn:se:liu:diva-118094 
Studies in Science and Technology Education

ISSN 1652-5051

\section{fontD}

1. Margareta Enghag (2004): MINIPROJECTS AND CONTEXT RICH PROBLEMS Case studies with qualitative analysis of motivation, learner ownership and competence in small group work in physics. (licentiate thesis) Linköping University

2. Carl-Johan Rundgren (2006): Meaning-Making in Molecular Life Science Education upper secondary school students' interpretation of visualizations of proteins. (licentiate thesis) Linköping University

3. Michal Drechsler (2005): Textbooks', teachers', and students' understanding of models used to explain acid-base reactions. ISSN: 1403-8099, ISBN: 91-85335-40-1. (licentiate thesis) Karlstad University

4. Margareta Enghag (2007): Two dimensions of Student Ownership of Learning during Small-Group Work with Miniprojects and context rich Problems in Physics. ISSN: 1651-4238, ISBN: 91-85485-31-4. (Doctoral Dissertation) Mälardalen University

5. Maria Åström (2007): Integrated and Subject-specific. An empirical exploration of Science education in Swedish compulsory schools. (Licentiate thesis) Linköping university

6. Ola Magntorn (2007): Reading Nature: developing ecological literacy through teaching. (Doctoral Dissertation) Linköping University

7. Maria Andreé (2007): Den levda läroplanen. En studie av naturorienterande undervisningspraktiker i grundskolan. ISSN: 1400-478X, HLS Förlag: ISBN 978-917656-632-9 (Doctoral Dissertation, LHS)

8. Mattias Lundin (2007): Students' participation in the realization of school science activities.(Doctoral Dissertation) Linköping University

9. Michal Drechsler (2007): Models in chemistry education. A study of teaching and learning acids and bases in Swedish upper secondary schools ISBN 978-91-7063-1122 (Doctoral Dissertation) Karlstad University

10. Proceedings from FontD Vadstena-meeting, April 2006.

11. Eva Blomdahl (2007): Teknik i skolan. En studie av teknikundervisning för yngre skolbarn. ISSN: 1400-478X, HLS Förlag: ISBN 978-91-7656-635-0 (Doctoral Dissertation, LHS)

12. Iann Lundegård (2007): På väg mot pluralism. Elever i situerade samtal kring hållbar utveckling. ISSN:1400-478X, HLS Förlag: ISBN 978-91-7656-642-8 (Doctoral Dissertation, LHS)

13. Lena Hansson (2007): "Enligt fysiken eller enligt mig själv?" - Gymnasieelever, fysiken och grundantaganden om världen. (Doctoral Dissertation) Linköping University. 


\section{Studies in Science and Technology Education \\ ISSN 1652-5051 \\ fontD}

14. Christel Persson (2008): Sfärernas symfoni i förändring? Lärande i miljö för hållbar utveckling med naturvetenskaplig utgångspunkt. En longitudinell studie i grundskolans tidigare årskurser. (Doctoral Dissertation) Linköping University

15. Eva Davidsson (2008): Different Images of Science - a study of how science is constituted in exhibitions. ISBN: 978-91-977100-1-5 (Doctoral Dissertation) Malmö University

16. Magnus Hultén (2008): Naturens kanon. Formering och förändring av innehållet i folkskolans och grundskolans naturvetenskap 1842-2007. ISBN: 978-91-7155-612-7 (Doctoral Dissertation) Stockholm University

17. Lars-Erik Björklund (2008): Från Novis till Expert: Förtrogenhetskunskap i kognitiv och didaktisk belysning. (Doctoral Dissertation) Linköping University.

18. Anders Jönsson (2008): Educative assessment for/of teacher competency. A study of assessment and learning in the "Interactive examination" for student teachers. ISBN: 978-91-977100-3-9 (Doctoral Dissertation) Malmö University

19. Pernilla Nilsson (2008): Learning to teach and teaching to learn - primary science student teachers' complex journey from learners to teachers. (Doctoral Dissertation) Linköping University

20. Carl-Johan Rundgren (2008): VISUAL THINKING, VISUAL SPEECH - a Semiotic Perspective on Meaning-Making in Molecular Life Science. (Doctoral Dissertation) Linköping University

21. Per Sund (2008): Att urskilja selektiva traditioner i miljöundervisningens socialisationsinnehåll - implikationer för undervisning för hållbar utveckling. ISBN: 978-91-85485-88-8 (Doctoral Dissertation) Mälardalen University

22. Susanne Engström (2008): Fysiken spelar roll! I undervisning om hållbara energisystem - fokus på gymnasiekursen Fysik A. ISBN: 978-91-85485-96-3 (Licentiate thesis) Mälardalen University

23. Britt Jakobsson (2008): Learning science through aesthetic experience in elementary school science. Aesthetic judgement, metaphor and art. ISBN: 978-91-7155-654-7. (Doctoral Dissertation) Stockholm university

24. Gunilla Gunnarsson (2008): Den laborativa klassrumsverksamhetens interaktioner En studie om vilket meningsskapande år 7-elever kan erbjudas i möten med den laborativa verksamhetens instruktioner, artefakter och språk inom elementär ellära, samt om lärares didaktiska handlingsmönster i dessa möten. (Doctoral Dissertation) Linköping University

25. Pernilla Granklint Enochson (2008): Elevernas föreställningar om kroppens organ och kroppens hälsa utifrån ett skolsammanhang. (Licentiate thesis) Linköping University

26. Maria Åström (2008): Defining Integrated Science Education and putting it to test (Doctoral Dissertation) Linköping University

27. Niklas Gericke (2009): Science versus School-science. Multiple models in genetics The depiction of gene function in upper secondary textbooks and its influence on students' understanding. ISBN 978-91-7063-205-1 (Doctoral Dissertation) Karlstad University 
Studies in Science and Technology Education

ISSN 1652-5051

\section{FontD}

28. Per Högström (2009): Laborativt arbete i grundskolans senare år - lärares mål och hur de implementeras. ISBN 978-91-7264-755-8 (Doctoral Dissertation) Umeå University

29. Annette Johnsson (2009): Dialogues on the Net. Power structures in asynchronous discussions in the context of a web based teacher training course. ISBN 978-91977100-9-1 (Doctoral Dissertation) Malmö University

30. Elisabet M. Nilsson (2010): Simulated "real" worlds: Actions mediated through computer game play in science education. ISBN 978-91-86295-02-8 (Doctoral Dissertation) Malmö University

31. Lise-Lotte Österlund (2010): Redox models in chemistry: A depiction of the conceptions held by upper secondary school students of redox reactions. ISBN 97891-7459-053-1 (Doctoral Dissertation) Umeå University

32. Claes Klasander (2010): Talet om tekniska system - förväntningar, traditioner och skolverkligheter. ISBN 978-91-7393-332-2 (Doctoral Dissertation) Linköping University

33. Maria Svensson (2011): Att urskilja tekniska system - didaktiska dimensioner i grundskolan. ISBN 978-91-7393-250-9 (Doctoral Dissertation) Linköping University

34. Nina Christenson (2011): Knowledge, Value and Personal experience - Upper secondary students' use of supporting reasons when arguing socioscientific issues. ISBN 978-91-7063-340-9 (Licentiate thesis) Karlstad University

35. Tor Nilsson (2011): Kemistudenters föreställningar om entalpi och relaterade begrepp. ISBN 978-91-7485-002-4 (Doctoral Dissertation) Mälardalen University

36. Kristina Andersson (2011): Lärare för förändring - att synliggöra och utmana föreställningar om naturvetenskap och genus. ISBN 978-91-7393-222-6 (Doctoral Dissertation) Linköping University

37. Peter Frejd (2011): Mathematical modelling in upper secondary school in Sweden An exploratory study. ISBN: 978-91-7393-223-3 (Licentiate thesis) Linköping University

38. Daniel Dufåker (2011): Spectroscopy studies of few particle effects in pyramidal quantum dots. ISBN 978-91-7393-179-3 (Licentiate thesis) Linköping University

39. Auli Arvola Orlander (2011): Med kroppen som insats: Diskursiva spänningsfält i biologiundervisningen på högstadiet. ISBN 978-91-7447-258-5 (Doctoral Dissertation) Stockholm University

40. Karin Stolpe (2011): Att uppmärksamma det väsentliga. Lärares ämnesdidaktiska förmågor ur ett interaktionskognitivt perspektiv. ISBN 978-91-7393-169-4 (Doctoral Dissertation) Linköping University

41. Anna-Karin Westman (2011) Samtal om begreppskartor - en väg till ökad förståelse. ISBN 978-91-86694-43-2 (Licentiate thesis) Mid Sweden University

42. Susanne Engström (2011) Att vördsamt värdesätta eller tryggt trotsa. Gymnasiefysiken, undervisningstraditioner och fysiklärares olika strategier för energiundervisning. ISBN 978-91-7485-011-6 (Doctoral Dissertation) Mälardalen University

43. Lena Adolfsson (2011) Attityder till naturvetenskap. Förändringar av flickors och pojkars attityder till biologi, fysik och kemi 1995 till 2007. ISBN 978-91-7459-233-7 (Licentiate thesis) Umeå University 
Studies in Science and Technology Education

ISSN 1652-5051

\section{FontD}

44. Anna Lundberg (2011) Proportionalitetsbegreppet i den svenska gymnasiematematiken - en studie om läromedel och nationella prov. ISBN 978-91-7393-132-8 (Licentiate thesis) Linköping University

45. Sanela Mehanovic (2011) The potential and challenges of the use of dynamic software in upper secondary Mathematics. Students' and teachers' work with integrals in GeoGebra based environments. ISBN 978-91-7393-127-4 (Licentiate thesis) Linköping University

46. Semir Becevic (2011) Klassrumsbedömning i matematik på gymnasieskolans nivå. ISBN 978-91-7393-091-8 (Licentiate thesis) Linköping University

47. Veronica Flodin (2011) Epistemisk drift - genbegreppets variationer i några av forskningens och undervisningens texter i biologi. ISBN 978-91-9795-161-6 (Licentiate thesis) Stockholm University

48. Carola Borg (2011) Utbildning för hållbar utveckling ur ett lärarperspektiv Ämnesbundna skillnader i gymnasieskolan. ISBN 978-91-7063-377-5 (Licentiate thesis) Karlstad University

49. Mats Lundström (2011) Decision-making in health issues: Teenagers' use of science and other discourses. ISBN 978-91-86295-15-8 (Doctoral Dissertation) Malmö University

50. Magnus Oscarsson (2012) Viktigt, men inget för mig. Ungdomars identitetsbygge och attityd till naturvetenskap. ISBN: 978-91-7519-988-7 (Doctoral Dissertation) Linköping University

51. Pernilla Granklint Enochson (2012) Om organisation och funktion av människokroppens organsystem - analys av elevsvar från Sverige och Sydafrika. ISBN 978-91-7519-960-3 (Doctoral Dissertation) Linköping University

52. Mari Stadig Degerman (2012) Att hantera cellmetabolismens komplexitet Meningsskapande genom visualisering och metaforer. ISBN 978-01-7519-954-2 (Doctoral Dissertation) Linköping University

53. Anna-Lena Göransson (2012) The Alzheimer A $\beta$ peptide: Identification of Properties Distinctive for Toxic Prefibrillar Species. ISBN 978-91-7519-930-6 (Licentiate thesis) Linköping University

54. Madelen Bodin (2012) Computational problem solving in university physics education - Students' beliefs, knowledge, and motivation. ISBN 978-91-7459-398-3 (Doctoral Dissertation) Umeå University

55. Lena Aretorn (2012) Mathematics in the Swedish Upper Secondary School Electricity Program: A study of teacher knowledge. ISBN 978-91-7459-429-4 (Licentiate thesis) Umeå University

56. Anders Jidesjö (2012) En problematisering av ungdomars intresse för naturvetenskap och teknik i skola och samhälle - Innehåll, medierna och utbildningens funktion.

ISBN 978-91-7519-873-6 (Doctoral Dissertation) Linköping University

57. Thomas Lundblad (2012) Simulerad verklighet i gymnasieskolans fysik: en designstudie om en augmented reality simulering med socio-naturvetenskapligt innehåll. ISBN 978-91-7519-854-5 (Licentiate thesis) Linköping University

58. Annie-Maj Johansson (2012) Undersökande arbetssätt i NO-undervisningen i grundskolans tidigare årskurser. ISBN 978-91-7447-552-4 (Doctoral Dissertation) Stockholm University 
Studies in Science and Technology Education

ISSN 1652-5051

\section{fontD}

59. Anna Jobér (2012) Social Class in Science Class. ISBN 978-91-86295-31-8 (Doctoral Dissertation) Malmö University

60. Jesper Haglund (2012) Analogical reasoning in science education - connections to semantics and scientific modeling in thermodynamics. ISBN 978-91-7519-773-9

(Doctoral Dissertation) Linköping University

61. Fredrik Jeppsson (2012) Adopting a cognitive semantic approach to understand thermodynamics within science education. ISBN 978-91-7519-765-4 (Doctoral Dissertation) Linköping University

62. Maria Petersson (2012) Lärares beskrivningar av evolution som undervisningsinnehåll i biologi på gymnasiet.ISBN 978-91-7063-453-6 (Doctoral Dissertation) Karlstad University

63. Henrik Carlsson (2012) Undervisningsform, klassrumsnormer och matematiska förmågor. En studie av ett lokalt undervisningsförsök för elever med intresse och fallenhet för matematik. ISBN 978-91-86983-89-5 (Licentiate thesis) Linnaeus University)

64. Anna Bergqvist (2012) Models of Chemical Bonding. Representations Used in School Textbooks and by Teachers and their Relation to Students' Understanding. ISBN 97891-7063-463-5 (Licentiate thesis) Karlstad University

65. Nina Kilbrink (2013) Lära för framtiden: Transfer i teknisk yrkesutbildning. ISBN 978-91-7063-478-9 (Doctoral Dissertation) Karlstad University

66. Caroline Larsson (2013) Experiencing Molecular Processes. The Role of Representations for Students' Conceptual Understanding. ISBN 978-91-7519-607-7 (Doctoral Dissertation) Linköping University

67. Anna-Karin Carstensen (2013) Connect Modelling Learning to Facilitate Linking Models and the Real World through Labwork in Electric Circuit Courses for Engineering Students ISBN 978-91-7519-562-9 (Doctoral Dissertation) Linköping University

68. Konferensproceeding: 10-year Anniversary Meeting with the Scientific Committee

69. Marie Bergholm (2014) Gymnasieelevers kommunikativa strategier i matematikklassrummet. En fallstudie av ett smågruppsarbete om derivata ISBN 97891-7519-306-9 (Licentiate thesis) Linköping University

70. Ingrid Lundh (2014) Undervisa Naturvetenskap genom Inquiry - En studie av två högstadielärare. ISBN 978-91-7519-285-7 (Licentiate thesis) Linköping University

71. Nils Boman (2014) Personality traits in fish - implications for invasion biology ISBN:978-91-7601-097-6 (Licentiate thesis) Umeå University

72. Torodd Lunde (2014) När läroplan och tradition möts - lärarfortbildning och syften med undersökande aktiviteter inom den laborativa NO-undervisningen i grundskolans senare del. ISBN: 978-91-7063-577-9 (Licentiate thesis) Karlstad University

73. Martin Eriksson (2014) Att ta ställning - gymnasieelevers argumentation och beslutsfattande om sociovetenskapliga dilemman. ISBN 978-91-7063-588-5 (Licentiate thesis), Karlstad University

74. Annalena Holm (2014) Mathematics Communication within the Frame of Supplemental Instruction. Identifying Learning Conditions. ISBN 978-91-7623-112-8 (Licentiate thesis) Lund University 
Studies in Science and Technology Education

ISSN 1652-5051

\section{fonkd}

75. Daniel Olsson (2014) Young people's 'Sustainability Consciousness' - Effects of ESD implementation in Swedish schools. ISBN 978-91-7063-594-6. (Licentiate thesis) Karlstad University

76. Marlene Sjöberg (2014) Möjligheter I kollegiala samtal om NO-undervisning och bedömning. https://gupea.ub.gu.se/handle/2077/24063 (Licentiate thesis) Gothenburg University.

77. Teresa Berglund (2014) Student 'Sustainability Consciousness' and Decision-Making on Sustainability Dilemmas. Investigating effects of implementing education for sustainable development in Swedish upper secondary schools. ISBN 978-91-7063599-1 (Licentiate thesis) Karlstad University

78. Elisabet Mellroth (2014) High achiever! Always a high achiever? A comparison of student achievements on mathematical tests with different aims and goals. ISBN 97891-7063-607-3 (Licentiate thesis) Karlstad University

79. Jenny Green (2014) Elevers användande av formativ återkoppling i matematik. ISBN 978-91-7519-164-5 (Licentiate thesis) Linköping University

80. Klara Kerekes (2014) Undervisning om växande geometriska mönster-en variationsteoretisk studie om hur lärare behandlar ett matematiskt innehåll på mellanstadiet. ISBN: 978-91-7519-135-5 (Licentiate thesis) Linköping University

81. Cecilia Axell (2015) Barnlitteraturens tekniklandskap: en didaktisk vandring från Nils Holgersson till Pettson och Findus. ISBN 978-91-7519-227-7 (Doctoral Dissertation) Linköping University.

82. Jan Forsgren (2015) Synthesis and characterization of catalysts for hydrogen production from water ISBN 978-91-7601-206-2.(Licentiate thesis) Umeå University

83. Maria Eriksson (2015) Att kommunicera naturvetenskap i nationella prov: En studie med andraspråksperspektiv. ISBN 978-91-7519-138-6 (Licentiate thesis) Linköping University

84. Tomas Jemsson (2015) Time correlated single photon spectroscopy on pyramidal quantum dots. ISBN 978-91-7519-143-0 (Licentiate thesis) Linköping University

85. Helen Hasslöf (2015) The Challenge of Education for Sustainable Development. Qualification, social change and the political ISBN: 978-91-7519-127-0 (Doctoral Dissertation) Linköping University.

86. Johan Sidenvall (2015) Att lära sig resonera - Om elevers möjligheter att lära sig resonera matematiskt. ISBN 978-91-7519-100-3 (Licentiate thesis) Linköping University.

87. Jonas Jäder (2015) Elevers möjligheter till lärande av matematiska resonemang. ISBN 978-91-7519-099-0 (Licentiate thesis) Linköping University. 